\title{
Marcin Łukasz Majewski
}

\section{Młynarstwo i piekarstwo w Piotrkowie w XVI-XVIII wieku}

\author{
Słowa kluczowe: młynarstwo, piekarstwo, Piotrków, miasto, ceny \\ Key words: milling, baking, Piotrków, town, prices
}

\section{Wstęp. II. Młyny. III. Młynarze. IV. Piekarstwo. V. Ceny chleba} w Piotrkowie w XVI-XVIII wieku

\section{Wstęp}

Młynarstwo było jednym z najważniejszych rzemiosł, ściśle związanym z życiem codziennym mieszkańców miast, miasteczek i wsi dawnej Rzeczpospolitej. Młyn jako miejsce, w którym zboże było przetwarzane na mąkę, oraz w którym śrutowano słód, zaopatrywał lokalne społeczności w podstawowe produkty niezbędne do wypieku chleba i produkcji piwa — dwóch najważniejszych produktów żywnościowych średniowiecza i doby nowożytnej. Nic więc dziwnego, że istotna rola młynarskiego rzemiosła doczekała się już wielu opracowań1.

W dobie staropolskiej Piotrków należał do grupy miast średnich, licząc w drugiej połowie XVI w. ponad 2000 mieszkańców ${ }^{2}$. Czyniło go to największym ośrodkiem miejskim województwa sieradzkiego, do tego istotnym w skali całego kraju ze względu na odbywające się tu wydarzenia polityczne ${ }^{3}$. W wiekach XV i XVI Piotrków był miejscem zjazdów sejmowych, zaś w latach 1578-1792 obrad Trybunału Koronnego. Pomimo dużego znaczenia miasta w dobie staropolskiej wiele problemów badawczych dotyczących jego przeszłości, w tym badania nad dziejami młynarstwa oraz piekarstwa, nie były przedmiotem zainteresowania badaczy. Stosunkowo najwięcej miejsca zagadnieniom związanym z piekarstwem poświęcił wybitny historykregionalista Michał Rawita-Witanowski. W swojej monumentalnej pracy ukończonej w $1931 \mathrm{r}$. zajął się historią funkcjonujących w mieście organizacji cechowych, w tym dziejami cechu piekarskiego. Badacz ograniczył się przy tym jedynie do bardzo ogólnego zarysu działalności piotrkowskich piekarzy. Witanowski korzystał z niezachowanych do naszych czasów, najstarszych,

1 Z nowszych prac dotyczącej tej tematyki zob.: Długokęcki W., Kuczyński J., Pospieszna B. 2004; Kizik E. 2008; Gadocha M. 2011; Kubicki R. 2012; Plisiecki P. 2015; Rzepkowski K. 2015; Szymański A. 2017; Żaba A. 2017.

2 Rutkowski H. 1967, s. 48. Szacunkowa liczba ludności Piotrkowa uwzględnia jedynie mieszkańców zamieszkałych w obrębie murów miejskich. Do naszych czasów nie zachowały się źródła, które pozwoliłby określić zaludnienie przedmieść. Liczba mieszkańców miasta okresowo wzrastała w czasie obrad sejmowych, które ściągały na nie, poza szlachtą i wszystkimi innymi zainteresowanymi obradami, także sporą liczbę kupców i rzemieślników. To samo zjawisko, choć na mniejszą skalę, występowało także w późniejszym okresie, gdy Piotrków był miejscem obrad Trybunału Koronnego. Nie dysponujemy obliczeniami stanu zaludnienia Piotrkowa dla wieków XVII i XVIII. Podjęcie badań w tym zakresie, choć wymagające pracochłonnej kwerendy, byłoby niezwykle pożądane.

3 Rutkowski H. 1998, s. 91. 
bo pochodzących z połowy XVIII w. ksiąg cechowych. Niestety nie wykorzystał bezpowrotnie utraconego, cennego materiału źródłowego w sposób pełniejszy. Młynarstwu i samym młynom Witanowski poświęcił zaledwie kilka wzmianek, wskazując tylko ich lokalizację

Niewiele miejsca młynarstwu i piekarstwu poświęcił także Henryk Rutkowski w artykule na temat życia miasta w okresie obrad sejmowych i trybunalskich. Historyk spożytkował zachowane szesnastowieczne lustracje starostwa piotrkowskiego oraz rejestry podatkowe z tego czasu, wymieniając młyny funkcjonujące w Piotrkowie oraz wskazując liczbę mieszczan trudniących się piekarstwem ${ }^{5}$. Podobnie zagadnienia te zostały przedstawione przez Ryszarda Rosina w jego badaniach nad średniowiecznym Piotrkowem ${ }^{6}$. Poza wyżej wymienionymi historykami, problemu piotrkowskiego młynarstwa i piekarstwa w dobie staropolskiej nie podjęli inni badacze. Zagadnienia te zostały pominięte przez Krzysztofa Pacelta ${ }^{7}$ i Bohdana Baranowskiego ${ }^{8}$, mimo że przedmiotem ich prac było życie gospodarcze Piotrkowa w stuleciach od XVI do XVIII. Miejskie młynarstwo znalazło się również poza tematyką poruszaną przez autora pionierskiej, i jak dotąd jedynej pracy o układzie urbanistycznym Piotrkowa, Kazimierza Głowackiego 9 . Brak wzmianek na ten temat może dziwić, gdyż poza przedstawieniem przemian w urbanistyce miasta od średniowiecza aż po wiek XX, badacz dużo miejsca w swojej monografii poświęcił życiu wewnętrznemu ośrodka. Na funkcjonowanie piotrkowskich młynów w XVI-XVIII wieku zwrócił uwagę Tomasz Kruz w swoim studium o piotrkowskim browarnictwie, przy czym autor nie prowadził własnych badań, korzystając z istniejących już opracowań ${ }^{10}$. Działalność młynów w kontekście rzemiosła piwowarskiego została omówiona przez piszącego te słowa w monografii dotyczącej piwowarstwa miejskiego w Piotrkowie w XVI-XVIII w. ${ }^{11}$

Wpływ na niezadowalający stan badań nad tym zagadnieniem miała niewątpliwie utrata w czasie drugiej wojny światowej kluczowych dla przeszłości miasta źródeł, skutecznie zniechęcając historyków nie tylko do studiów nad dziejami tytułowych dziedzin wytwórczości, ale także historii miasta w epoce staropolskiej w ogóle.

Niniejszy artykuł powstał na podstawie zachowanych źródeł pisanych z XVI-XVIII w., przede wszystkim: rejestrów podatkowych z XVI stulecia, akt Metryki Koronnej, lustracji starostwa piotrkowskiego z lat 1564-1565, 1569, 1628, 1661, 1765 i 1789, ksiąg piotrkowskiego cechu rzeźniczego i Konfraterni Kupieckiej z XVI-XVIII w., lustracji parafii pw. św. Jakuba z 1780 r. oraz jej akt metrykalnych z wieków XVII i XVIII.

\section{Mtyny}

O początkach piotrkowskiego młynarstwa niewiele wiadomo. Najstarsze informacje poświadczające istnienie młynów w Piotrkowie pochodzą dopiero z drugiej połowy XIV w. W akcie sprzedaży piotrkowskiego wójtostwa z 23 lutego 1391 r. młyn został wymieniony obok łaźni, stawu rybnego oraz pól Obrytka i Zdzieniowa (Zdzienitka) jako część jego uposażenia ${ }^{12}$. Ponieważ uposażenie wójta było określane przy lokacji miasta, można przyjąć, że wspomniany w powyższym akcie młyn istniał przed rokiem 1313, gdy Piotrków po raz pierwszy został określony jako civitas ${ }^{13}$.

${ }^{4}$ Rawita-Witanowski M. 2017, s. 741-745.

5 Rutkowski H. 1967, s. 43-74.

${ }^{6}$ Rosin R. 1967, s. 11-42.

7 Pacelt K. 1989, s. 73-83.

${ }^{8}$ Baranowski B. 1989, s. 84-96.

9 Głowacki K. 1984.

10 Kruz T. 2005.

11 Majewski M.Ł. 2019.

12 Lustracja. 1996, s. 16.

13 Rosin R. 1967, s. 25. 
Przyjmując argumentację Ryszarda Rosina, który stwierdził, że pierwotna lokacja Piotrkowa musiała mieć miejsce przed lokacją pobliskiego Sulejowa, czyli najpóźniej przed rokiem 1292, budowę młyna wójtowskiego można przesunąć na koniec XIII w. ${ }^{14}$

Nie zachowały się szczegółowe opisy wyglądu młyna wójtowskiego. Na podstawie szesnastowiecznych rejestrów podatkowych można jedynie przyjąć, że był to młyn wodny i miał jedno koło ${ }^{15}$. Położony był poza murami miejskimi, na wschód od młyna słodowego, obok łąk należących do piotrkowskiego wójta ${ }^{16}$. W wyniku klęsk żywiołowych i działań wojennych W ciągu stuleci XVI-XVIII młyn kilkakrotnie ulegał zniszczeniu. W 1530 r. młyn wójtowski został zwolniony z podatku, co może sugerować, że w tym czasie musiał ucierpieć wskutek pożaru ${ }^{17}$. Największe straty przyniósł jednak pożar w 1786 r., w wyniku którego młyn spłonął doszczętnie. Skala zniszczeń zarówno w mieście, jak i na obszarze wójtostwa była tak duża, że odbudowa młyna trwała długi czas. Trzy lata po katastrofie odbudowywany młyn nie był jeszcze ukończony, co zaznaczyli w inwentarzu wójtostwa urzędnicy królewscy, przeprowadzający lustrację starostwa piotrkowskiego: „Za młynkiem do fary należącym [tj. za młynem słodowym], wodę z tamtego młynka tylko mający, nowo wystawiony, nie dokończony, gontami pokryty ze stawym [stawem] nowo wyrżniętym" 18 .

Na podstawie zachowanych przekazów nic nie wiadomo o produkcji prowadzonej w opisywanym młynie. Najpewniej zajmował się on mieleniem zbóż uprawianych na obszarze wójtostwa: pszenicy, jęczmienia, owsa i żyta ${ }^{19}$. Prawdopodobnie był również wykorzystywany w produkcji piwowarskiej, gdyż wójt posiadał nieopodal browar wraz ze słodownią ${ }^{20}$.

Dla mieszczan piotrkowskich zamieszkujących miasto zarówno intra muros, jak i na przedmieściach, największe znaczenie miały młyny królewskie. Wyłącznie w tego typu młynach mieszczanie mieli prawo mielenia mąki i śrutowania słodu, artykułów niezbędnych w produkcji dwóch głównych, a zarazem najbardziej powszechnych produktów żywnościowych. W Piotrkowie istniały dwa młyny królewskie: słodowy ${ }^{21}$ oraz tzw. Bugaj. Podobnie jak młyn wójtowski, oba najprawdopodobniej zostały wzniesione w czasie lokacji Piotrkowa. Pierwsza wzmianka o młynie słodowym pochodzi z wystawionego przez króla Kazimierza Jagiellończyka dokumentu z 28 sierpnia 1476 r., w którym zezwolił on staroście i tenutariuszowi piotrkowskiemu, Janowi z Kurozwęk, na wykupienie od młynarza Michała Kopcia trzeciej miary śrutowanego w młynie słodu ${ }^{22}$. Młyn ten położony był za miastem, na terenie tzw. Wielkiej Wsi, a jego dokładną lokalizację podają akty z 16 marca i 11 kwietnia 1509 r. Młyn usytuowany był naprzeciwko piotrkowskiego zamku królewskiego, nieopodal domów Tomasza Grudy i garncarza Tomasza ${ }^{23}$. W źródłach, poza nazwą „słodowy”, zapisywany był również jako „Poznański”, „Psonka” oraz „Weśredni”. Na podstawie pobieżnej analizy szesnastowiecznych rejestrów

${ }^{14}$ Rosin R. 1989, s. 15.

${ }^{15}$ AGAD, ASK I, sygn. 24, k. 326, 495, 641v.

${ }^{16}$ APPT, ZAKKiZW, sygn. 79, s. 26 a.

${ }^{17}$ AGAD, ASK XLVI, sygn. 25, k. 97v.

${ }^{18}$ Lustracja. 2007, s. 61.

19 AGAD, ASK XLVI, sygn. 107, k. 37v.

${ }^{20}$ AGAD, ASK XLVI, sygn. 107, k. 37.

${ }^{21}$ Istnienie specjalnych młynów przeznaczonych wyłącznie do śrutowania słodu było związane z wymogami produkcji piwowarskiej. Słód nie mógł być mielony w młynie tak jak mąka, ponieważ jego zbytnie rozdrobnienie powodowało problemy z filtracją brzeczki. Z tego powodu słód nie był mielony, ale śrutowany. W tym celu kamienie młyńskie musiały być odpowiednio nastawione, a ich rozstawu nie można było ciągle zmieniać. Koła młyńskie wymagały również odpowiedniej regulacji szybkości. Zapewne z tego powodu uznano za bardziej pożądane budowanie specjalnych młynów słodowych, zob.: Dembińska 1973, s. 232.

${ }^{22} \mathrm{BCz}$, sygn. 590 Perg.

${ }^{23}$ AGAD, MK, sygn. 23, k. 574; sygn. 24, k. 90. 
podatkowych, Ryszard Rosin błędnie uznał młyn „Weśredni” za odrębny od słodowego, do tego nie wzmiankowany przez żadne źródła, poza rejestrem podatkowym z roku $1511^{24}$. W rzeczywistości młyn pod tą nazwą odnotowywany był w spisach skarbowych regularnie. Wymieniają go rejestry z lat: 1508, 1511, 1512, 1515, 1518, 1530, 1534, 1535, 1553, 1563, 1565 i $1577^{25}$. Młyna nazywanego „Weśrednim” nie ma jedynie w pięciu rejestrach z lat: 1532, 1538, 1552, 1540 i $1570^{26}$. Dowodem na to, że młyn ten jest tożsamy z młynem słodowym, jest akt króla Zygmunta III z 28 marca 1624 r., w którym monarcha zatwierdził kontrakt dzierżawy młyna zawarty 21 listopada 1623 r. między starostą piotrkowskim Albrechtem Starołęskim, a młynarzem Stanisławem Pszonką. Dokument ten mówi o wydzierżawionym przez Pszonkę „młynie wesrednim albo Poznanskim nazwanym"27. Z lustracji starostwa piotrkowskiego z lat 1564-1565 ${ }^{28}$ oraz $1569^{29}$ wiadomo natomiast, że nazwa młyn Poznański odnosiła się do młyna słodowego. Co więcej, w kolejnej lustracji — z 1628 r. urzędnicy królewscy odnotowali „Młyn Poznański z dawna, a teraz Psonka rzeczony" ${ }^{\prime 30}$, określony tak bez wątpienia od nazwiska dzierżawiącego go od 1623 r. młynarza. Również lustracja piotrkowskiej fary wymienia „młynek przedtym we Sredni teraz zas słodowy zwany" ${ }^{31}$. O tym, że młyn słodowy oraz Weśredni to ten sam obiekt, świadczą zresztą rejestry podatkowe, na które powoływał się Rosin. W rejestrach z lat 1508, 1511, 1512, 1515 i 1530 figurują dwa młyny: słodowy i weśredni, ale informacja o opłaconym podatku pojawia się tylko przy jednym $\mathrm{z}$ nich ${ }^{32}$. Osobny podatek został odnotowany jedynie w trzech rejestrach, z lat: 1518, 1563 i $1577^{33}$. Taki sposób zapisu jest jednak łatwo wytłumaczalny, ponieważ podatek odprowadzano od każdego koła młyńskiego.

Nie istniały więc dwa osobne młyny, ale jeden posiadający dwa koła. Stosowane w trzech wymienionych wyżej rejestrach rozróżnienie mogło być spowodowane faktem, że jedno z kół służyło do śrutowania słodu, zaś drugie do mielenia mąki. Funkcjonowanie we młynie dwóch kół poświadcza lustracja kościoła farnego ${ }^{34}$. Warto również zauważyć, że w pięciu rejestrach, w których nie został odnotowany młyn o nazwie „Weśredni”, wymieniony został młyn słodowy ${ }^{35}$ i odwrotnie: w rejestrach z lat $1534^{36}, 1535^{37}$ i $1553^{38}$, w których nie ma młyna słodowego, jest wpisany młyn Weśredni. W rejestrze z 1532 r. młyn nie pojawia się pod żadną z nazw ${ }^{39}$, co było spowodowane najpewniej zwolnieniem go z powinności podatkowej z powodu zniszczenia przez pożar, który miał miejsce w Piotrkowie w 1531 r. ${ }^{40}$ Ryszard Rosin błędnie przypuszczał, że młyn Weśredni mógł być tożsamy z uwzględnionym w źródłach młynem o nazwie Kleszcz ${ }^{41}$.

24 Rosin R. 1989, s. 35.

${ }_{25}$ AGAD, ASK I, sygn. 24, k. 326, 495; sygn. 25, k. 2v, 16v, 29v, 43v, 55v, 68v, 97v, 253v; sygn. 26, k. 301v, 534v, 724; sygn. 79, k. 64v.

${ }^{26}$ AGAD, ASK I, sygn. 24, k. 641v; sygn. 25, k. 130v, 305v; sygn. 26, k. 157v, 785.

${ }^{27}$ AGAD, MK, sygn. 171, k. 132v.

${ }^{28}$ Lustracja. 1963, s. 31.

29 AGAD, ASK I, sygn. 103d, k. 129v.

${ }^{30}$ Lustracja. 1969, s. 24.

31 APPT, ZAKKiZW, sygn. 9, k. 26a.

32 AGAD, ASK I, sygn. 25, k. 2v, 16v, 29v, 55v, 97v.

33 AGAD, ASK I, sygn. 25, k. 68v, 253v, 724.

34 APPT, ZAKKiZW, sygn. 9, s. 26a.

${ }^{35}$ AGAD, ASK I, sygn. 24, k. 641v; sygn. 25, k. 130v, 305v; sygn. 26, k. 157v, 785.

${ }^{36}$ AGAD, ASK I, sygn. 79, k. 64v.

37 AGAD, ASK I, sygn. 24, k. 495.

${ }^{38}$ AGAD, ASK I, sygn. 26, k. 301v.

39 AGAD, ASK I, sygn. 25, k. 305v.

40 Żerek-Kleszcz H. 1989, s. 160.

41 Rosin R. 1989, s. 35. 
W istocie Kleszcz to określenie innego młyna, działającego we wsi Świerczów (obecnie część Piotrkowa) $)^{42}$, w XVI w. zwanego kuczowskim ${ }^{43}$.

W XVIII w. młyn słodowy nazywany był również farnym, co wiązało się z zapisem na rzecz znajdującego się w kościele parafialnym ołtarza św. Walentego. Część dochodów z młyna altaria otrzymywała najprawdopodobniej już w XV w. Jak ważny był to zapis świadczy fakt, że dochody z młyna były najważniejszą częścią uposażenia ołtarza ${ }^{44}$. W drugiej połowie XVIII stulecia, na mocy wyroku sądu asesorskiego z 1757 r., zostały one przyznane altaryście ołtarza Świętej Trójcy ${ }^{45}$, stąd w źródłach osiemnastowiecznych był również niekiedy nazywany młynem trynitarskim ${ }^{46}$.

Nie zachowały się żadne szesnastowieczne i siedemnastowieczne opisy młyna. Lustracje starostwa piotrkowskiego z lat 1564-1565, 1569 i 1628 informują jedynie o wysokości uiszczanego staroście czynszu ${ }^{47}$. Akt dzierżawy młyna z 21 listopada 1623 r. wskazuje na duże uszkodzenia powstałe w czasie dzierżawienia go przez poprzednią właścicielkę — Annę Kuczkowską. Młyn miał w tym czasie zepsute pogródki, upusty, groblę oraz zamulony staw, co wiązało się z koniecznością poniesienia znacznych wydatków przez kolejnego dzierżawcę ${ }^{48}$. Dokładny opis młyna słodowego znajduje się w osiemnastowiecznej lustracji piotrkowskiej fary: „W tym młynku jest izba jedna z piecem i kominkiem w roku 1779 postawionym, z tej izby komory dwie, w sieni komin na czterech słupach nowo postawiony, dalej młynica, w której ściany dobre prócz jednej od podwórza, do której przycieś wygniła, koła wodne dwa w roku 1775 nowo sprawione, także koło paleczne jedno nowe, drugie stare, skrzynia pytlowa nowa, do słodu druga przerabiana, kamieni cztery z tych jeden w roku 1779 sprawiony, wrzeciona dwa jedno stare, drugie nowe. Czopy dwa, pytle stare dwa, ryfy dwie, pogrodki w roku 1780 nowe postawione o trzech oknach, także upust, grobla zawieszona w roku tymże, koryta stare dwa. Ten budynek młynka jest gontami pokryty, przy nim stodółka jedna, stajenki dwie"49.

Lustracje starostwa piotrkowskiego informują o ilości przerabianego w młynie słodu. W latach 1564-1565 młyn śrutował rocznie do 2305 korców, w 1569 r. — do 1800, w 1628 r. — $900^{50}$, zaś w 1661 jedynie ok. $600^{51}$. Podobne dane dla XVIII w. nie zachowały się, a sam młyn nie jest wymieniany w lustracjach starostwa. Brak wzmianek o tym obiekcie spowodowany był wspomnianym już zapisaniem go kościołowi parafialnemu ${ }^{52}$.

Drugi młyn królewski położony był na wschód od miasta, na stawie Bugaj, od którego wziął swoją nazwę ${ }^{53}$. Krótki opis młyna zawiera lustracja starostwa piotrkowskiego z lat 1564-1565: „Młyn Bugai jest na stawie Bugayu, ma 3 koła korzeczniki, a czwarte stępne, na którym też folusz jest, różno wydawa wymiar: kiedy ma wody dostatek, a nie przeschnie, da żyta kor 140 c.v.u, pszenice kor. 5 c.v.u, foluszowego do roku przychodzi fl. 1 c.v.u" ${ }^{\text {}}$.

42 AAŁ, AMPPT, sygn. 71, Księga ochrzczonych 1653-1675, k. 219v; AAŁ, AMPPT, sygn. 71, Księga ochrzczonych 1676-1700, s. 109. Albert Kleszcz dzierżawił młyn kuczowski w 1673 r. Kolejna informacja o tym młynie pochodzi z 1683 r. Jego dzierżawcą był wtedy Paweł Lanuszka, a młyn występował już pod nazwą Kleszcz.

${ }^{43}$ AGAD, ASK I, sygn. 26, k. 724, 785.

44 Majewski M.Ł. 2019, s. 77 i n.

45 Majewski M.Ł. 2019, s. 78.

46 AAŁ, AMPPT, sygn. 72, Księga ochrzczonych 1748-1778, s. 282.

${ }^{47}$ Lustracja. 1963, s. 31; Lustracja. 1969, s. 24; AGAD, ASK I, sygn. 103d, k. 129v.

48 AGAD, MK, sygn. 171, k. 132v.

49 APPT, ZAKKiZW, sygn. 79, s. 26a.

50 Majewski M.Ł. 2019, s. 98, 102.

51 Lustracja. 1996, s. 17 i n.

52 Młyn słodowy nie był lustrowany także w 1661 r., ale było to najpewniej spowodowane jego zniszczeniem w czasie wojny polsko-szwedzkiej.

53 Rosin R. 1989, s. 34.

${ }^{54}$ Lustracja. 1963, s. 31. 
Wydajność młyna była zależna od poziomu napędzającej koła wody. W tym celu zresztą woda W stawie była sztucznie spiętrzana ${ }^{55}$, choć nie zawsze odnosiło to pożądany skutek. W lustracji z 1661 r. zapisano: „podczas suchego lata nie zawsze wszytkiemi trzema kołami miele, także podczas resolucyjej wiosennej i powodzi, gdyż go woda zatapia" ${ }^{56}$.

Tłumaczy to notowane w niektórych rejestrach podatkowych odprowadzanie podatku jedynie za dwa koła młyńskie ${ }^{57}$.

Nie wiadomo, czy od samego początku istnienia młyna był on wyposażony w koło folusznicze. Najprawdopodobniej folusz nie był pierwotnie częścią młyna bugajskiego, a stanowił osobną budowlę, wzniesioną w innej części miasta. Wskazywałby na to przywilej króla Władysława Jagiełły wydany w Sandomierzu 8 września 1412 r., w którym monarcha zezwolił mieszczanom piotrkowskim na wzniesienie folusza przy drodze wiodącej do Krakowa, a więc na południe od murów miejskich ${ }^{58}$. Według Ryszarda Rosina, dalsze losy tego obiektu pozostają nieznane ${ }^{59}$, ale najpewniej wybudowany na gościńcu krakowskim folusz jest tożsamy z tajemniczym, wymienionym w Liber Beneficiorum Jana Łaskiego urządzeniem zwanym pradłem ${ }^{60}$. Budowla ta uległa najpewniej zniszczeniu lub nie była w stanie należycie funkcjonować, stąd zdecydowano się zamontować koło folusznicze w młynie bugajskim.

W pierwszej połowie XVII w. stan techniczny młyna Bugaj pozostawiał wiele do życzenia. Według aktu dzierżawy młyna z 28 maja 1615 r. naprawy wymagały grobla, upust i pogródki ${ }^{61}$. W dokumencie winą za stan młyna obarczono dzierżawiącego go młynarza i jego żonę ${ }^{62}$, ale zmiana dzierżawcy niewiele pomogła, skoro w lustracji starostwa piotrkowskiego z roku 1628 zapisano: „Drugi młyn, Bugay nazwany, jest na stawie Bugaiu, który staw błotem zalaz, według relacyjej młynarzowej, po większej części, dlaczego ryby przechować się nie mogą. Ma 3 koła korzeczne, a czwarte, stępne spustoszało, za czym i folusz zaginął. Z którego folusza antiquitus dawano arendy po fl. 60 na rok. Teraz, iż go niemasz, nic z niego nie idzie"

Bardziej szczegółowy opis młyna zawiera lustracja starostwa piotrkowskiego z 1765 r. Dowiadujemy się z niej, że młyn był „z drzewa ciosanego z młynicą w węgły budowany” i nie był w najlepszym stanie technicznym. Naprawy wymagały m.in. pogródki i koła na młynicy, mocno już w tym czasie zdezelowane ${ }^{64}$. Stan młyna poprawił się w ciągu następnych lat, na co wskazuje opis młyna w lustracji z 1789 r.: „Młyn na stawie Bugay zwanym o sieni, młynicy, izbie i komorze z drzewa tartego w węgieł postawiony, stary, gontami pokryty. Wrót do sieni podwójnych na biegunach z wrzeciądzami dwoje. Drzwi do izby z wrzeciądzem i haczykiem, do komory z wrzeciądzem i z komory, z zasuwą. Wszystkie na zawiasach i hakach żelaznych. W izbie okien w tafelki ćwiartkowe w drzewie osadzonych, dobrych 2. Komin kapiasty. Piec z cegły. Połap z tarcic i w komorze takiż. W sieni komin lepiony, na dach wywiedziony, reparacyji potrzebujący [...]. Do młynicy drzwi nie masz, tylko odrzwi. W niej okien niewielkich w tafelki ćwiartkowe, złych 2. Podłoga przez większą połowę młynicy teraz nowo dana. Komin murowany, na dach wywiedziony, reparacyji potrzebujący. Pod z bali, na który wschodki. Kół wodnych 3, palecznych 3. Kamieni zwierzchnych 2, spodnich 2. Z tych, zwierzchni jeden nowy. Piąty jagielny. Wrzecion 3. Ryft na walcach 12, czopów u wałów 6. Ryft

55 Rutkowski H. 1998, s. 95.

56 Lustracja. 1996, s. 20.

${ }^{57}$ AGAD, ASK I, sygn. 25, k. 253v.

58 Czuba A., Gąsior M., Kotewicz R. 1993, s. 27; Rosin R. 1989, s. 35.

59 Rosin R. 1989, s. 35.

${ }^{60}$ Łaski J. 1881, t. II, s. 225.

${ }^{61}$ AGAD, MK, sygn. 160, k. 101v.

${ }^{62}$ AGAD, MK, sygn. 160, k. 101.

${ }^{63}$ Lustracja. 1969, s. 24.

${ }^{64}$ AGAD, ASK XLVI, sygn. 107, k. 34v, 35. 
na cewiach 6. Panewek 3. Paprzyc 3. Buksów w kamieniach 2. Skrzynia jedna nowa, druga stara. Koszów z korytkami 3. Ogrodzenie od stawu z sztachet i wrota nowo dane z tarcic, przy których 2 przęsła parkanu" ${ }^{65}$.

Młyn zajmował się głównie mieleniem zboża na mąkę, ale był także używany do produkcji kasz ${ }^{66}$ i śrutowania słodu, przy czym we młynie śrutowany był wyłącznie słód zamkowy ${ }^{67}$. W latach 1564-1565 młyn przerobił 140 korców żyta, 5 korców pszenicy i 81 korców owsa ${ }^{68}$. Dla wieków XVI i XVII nie są znane ilości ześrutowanego w młynie słodu. Dane takie pochodzą dopiero z lat 1762-1764, przy czym dotyczą one wyłącznie słodu jęczmiennego. I tak, w 1762 r. było to 112 korców, w 1763 r. - 130, zaś rok później - $128^{69}$.

Poza opisanymi powyżej młynami, szesnastowieczne rejestry podatkowe wymieniają jeszcze młyny dominikański i plebański. Data wzniesienia młyna przez zakonników dominikańskich jest nieznana. Po raz pierwszy młyn ten jest wzmiankowany w rejestrze podatkowym $\mathrm{z}$ roku $1518^{70}$. Słuszna wydaje się zatem hipoteza Ryszarda Rosina o otrzymaniu przez dominikanów prawa wystawienia młyna w czasie fundacji klasztoru, a więc w połowie XV w. ${ }^{71}$, choć historyk błędnie twierdził, że pierwsza wzmianka o tym młynie pochodzi dopiero z $1531 \mathrm{r}^{72}$ W rzeczywistości w tym roku, dnia 6 stycznia, piotrkowscy zakonnicy otrzymali nowy przywilej na wystawienie młyna ${ }^{73}$, który najpewniej uległ zniszczeniu w bliżej nieznanych okolicznościach. Młyn dominikański znajdował się w północnej części miasta, pomiędzy gruntami przedmieść Rokszyckiego i Bykowskiego ${ }^{74}$.

Z piotrkowskim konwentem dominikańskim związany był jeszcze młyn koński zbudowany na podwórzu klasztornym przez Szwedów okupujących Piotrków. Najeźdźcy zajmowali miasto we wrześniu i na początku października 1655 r., następnie od listopada 1655 do początku lipca 1656 r., zaś krótkotrwale od 3 kwietnia do 5 maja 1657 r. miasto zostało obsadzone przez garnizon sprzymierzonych ze Szwedami Brandenburczyków ${ }^{75}$. Budowa młyna nastąpiła zapewne podczas drugiej, półrocznej okupacji miasta i była wynikiem realizacji rozkazu wydanego przez króla szwedzkiego oblegającemu Piotrków generałowi Burchardtowi Müllerowi, który miał po zdobyciu miasta ufortyfikować je oraz utworzyć szpitale i magazyny żywnościowe ${ }^{76}$.

Po ostatecznym odbiciu miasta przez Stefana Czarnieckiego 5 maja 1657 r. ${ }^{77}$, prawo użytkowania młyna otrzymali zakonnicy. W młynie śrutowali słód na własne potrzeby, uzyskując w roku 1661 prawo nie uiszczania $\mathrm{z}$ tego tytułu podatku, pod warunkiem, że roczna miara śrutowanego w młynie końskim słodu nie przekroczy 12 korców $^{78}$. Dalsze losy tego młyna nie są znane. Wiadomo jedynie, że przeprowadzający lustrację starostwa piotrkowskiego urzędnicy królewscy nakazali, żeby przeniesiono go z podwórza klasztornego w bardziej odpowiednie miejsce ${ }^{79}$.

${ }^{65}$ Lustracja. 2007, s. 37 i n.

${ }^{66}$ Lustracja. 2007, s. 38.

${ }^{67}$ Lustracja. 1996, s. 20.

${ }^{68}$ Lustracja. 1963, s. 31.

${ }^{69}$ AGAD, ASK XLVI, sygn. 107, k. 49.

${ }^{70}$ AGAD, ASK I, sygn. 25, k. 69.

${ }^{71}$ Rosin R. 1967, s. 29.

72 Rosin R. 1967, s. 41, przyp. 103.

${ }^{73}$ MRPS, p. IV, s. 341.

${ }^{74}$ MRPS, p. IV, s. 341.

${ }^{75}$ Anusik Z. 1989, s. 145-147.

${ }^{76}$ Anusik Z. 1989, s. 145.

77 Anusik Z. 1989, s. 147.

${ }^{78}$ Lustracja. 1996, s. 7.

${ }^{79}$ Lustracja. 1996, s. 7. 
Własnym młynem dysponował również proboszcz piotrkowskiej fary. Należący do parafii młyn jest wzmiankowany jedynie w rejestrze podatkowym z $1538 \mathrm{r}^{80}$ Brak jakichkolwiek informacji o jego położeniu i wyglądzie. Brak wiadomości w pozostałych szesnastowiecznych rejestrach może sugerować, że młyn został zwolniony z podatków. Z całą pewnością istniał on przez długi czas, ponieważ wzmiankowany jest jeszcze w $1662 \mathrm{r}{ }^{81}$ Po tej dacie o młynie tym nie ma żadnych danych. Ponieważ, jak już wspomniano, w latach pięćdziesiątych XVIII w. kościół parafialny otrzymał zapis na użytkowanie młyna słodowego, można przypuszczać, że w tym czasie młyn plebański już nie istniał. Być może zapis na rzecz kościoła był spowodowany zniszczeniem młyna plebańskiego w wyniku klęski żywiołowej lub przez obce wojska.

Poza wymienionymi powyżej młynami, w osiemnastowiecznym Piotrkowie funkcjonowały także wiatraki (młyny wietrzne). Lustracja starostwa piotrkowskiego z $1789 \mathrm{r}$. wymienia trzy urządzenia tego typu ${ }^{82}$. Pierwszy z nich, zwany starym, został wzniesiony przed rokiem 1765, dwa kolejne w 1765 r. Młyny te zbudowano przy Trakcie Wrocławskim, wszystkie o jednakowej konstrukcji ${ }^{83}$ : „Pierwszy stary [młyn] [...] gontami pobity po bokach tarcicami i sznigami krzyzowemi na niego pierwsze schody z tarcic dobre $\mathrm{z}$ ktorych dziur na zawiasach hakach z wrzeciądzem skoblami 2 zelaznemi w pierwszey kondygnacyi skrzynia do pytla y otrębnica podłoga zwierzchnia y spodnia $z$ tarcic tamze cywia olowiane zelaznemi obręczami na od łączce od pytla ryfty zelazne idąc wyzey przy schodach kominek z cegly murowany schody takiesz iakie pierwsze do drugiego piętra gdzie kamieni dwa kosz do sypania zboza koło wałeczne na wale ryfty zelazne czop blacha w murtacie zelazna w poręczy antaba żelazna kołowrot do windowania zboża skrzynia do sypania wymiaru z tarcic na zawiasach hakach z wrzeciądzem y skoblami dwiema leszy trzy dobre cwierc [ćwierć] do sypania zboza [zboża]"84.

Działalność produkcyjna młynów wiatrakowych nie jest znana.

\section{Młynarze}

Choć młynarstwo było rzemiosłem obecnym w Piotrkowie od czasów lokacji, aż do pierwszej połowy XVII w. źródła nie wymieniają imion działających tu młynarzy. Wyjątkiem jest wspomniany już wcześniej akt królewski z 1476 r., w którym został wymieniony młynarz gospodarujący w młynie słodowym — Michał Kopeć ${ }^{85}$. Być może jednak za pierwszego znanego nam piotrkowskiego młynarza należałoby uznać Jakuba, który 29 listopada 1377 r. wydzierżawił w pobliskim Wolborzu młyn nad rzeką Moszczenicą. Akt dzierżawy nie podaje bliższych informacji na temat Jakuba, stąd nie wiadomo, czy przed przybyciem do Wolborza był on już dzierżawcą któregoś z okolicznych młynów. Dokument potwierdza natomiast jego związki z Piotrkowem wzmiankując, że był on synem Radosława z Piotrkowa ${ }^{86}$. Na podstawie tej informacji nie można przesądzić, czy Jakub wyuczył się rzemiosła w jednym z piotrkowskich młynów lub przed rokiem 1377 był dzierżawcą jednego z nich. Takiej możliwości nie można również wykluczyć.

Związki młynarza z danym młynem określały tzw. przywileje młyńskie wystawiane przez właścicieli poszczególnych obiektów. W zależności od postanowień konkretnego przywileju młynarze w średniowieczu i dobie nowożytnej dzielili się na trzy podstawowe grupy: młynarzy dziedzicznych, młynarzy dzierżawców oraz młynarzy najemnych. W Piotrkowie byli młynarze należący wyłącznie do drugiej grupy, choć trzeba nadmienić, że dzierżawa miała często charakter dożywotni. Jej podstawą był kontrakt, który młynarz zawierał z właścicielem młyna.

\footnotetext{
${ }^{80}$ AGAD, ASK I, sygn. 24, k. 641v.

${ }^{81}$ AAŁ, AMPPT, sygn. 71, Księga ochrzczonych 1653-1675, k. 98.

${ }^{82}$ Lustracja. 2007, s. 7.

${ }^{83}$ AGAD, ASK XLVI, sygn. 107, k. 35.

${ }^{84}$ AGAD, ASK XLVI, sygn. 107, k. 35.
} 
W aktach Metryki Koronnej zachowały się dwie umowy dzierżawne z lat 1615 i 1623 dotyczące funkcjonujących w Piotrkowie młynów królewskich. Pozwalają one na bliższe poznanie zasad najmu, a także obowiązków i przywilejów młynarskich.

Właściciel młyna stawał przed koniecznością znalezienia nowego młynarza-dzierżawcy w kilku przypadkach. Pierwszym była śmierć dotychczasowego dzierżawcy, drugim zakończenie dzierżawy przez młynarza i podjęcie przez niego pracy w innym młynie, trzecim wreszcie niewywiązywanie się z obowiązków zapisanych w kontrakcie. Na przykład w $1615 \mathrm{r}$. starosta piotrkowski tłumaczył poszukiwania nowego dzierżawcy młyna Bugaj faktem doprowadzenia go do opłakanego stanu przez dotychczasowych użytkowników — Jana Błuszczyka i jego żonę ${ }^{87}$. Niekiedy zresztą znaczący był więcej niż jeden czynnik. W kontrakcie na dzierżawę młyna słodowego, który w 1623 r. starosta piotrkowski zawarł ze Stanisławem Pszonką, powodem była samobójcza śmierć młynarzowej, a zarazem pozostawienie przez nią młyna w fatalnym stanie ${ }^{88}$.

Młynarz, który był zainteresowany dzierżawą, udawał się do właściciela młyna zgłaszając chęć objęcia młynarskich obowiązków. Tak było w przypadku Stanisława Pszonki, który dowiedziawszy się o samobójstwie młynarzowej osobiście przybył do starosty, prosząc o dzierżawę młyna słodowego ${ }^{89}$. Nowego dzierżawcy poszukiwali również sami starostowie. Kiedy w drugiej dekadzie XVII w. stan techniczny młyna bugajskiego coraz bardziej się pogarszał, starosta rozpoczął poszukiwania nowego najemcy. Dowiedziawszy się, że w pobliskim Przygłowie pracuje młynarz ceniony jako znakomity rzemieślnik i dobry gospodarz zaproponował mu objęcie młyna w dzierżawę ${ }^{90}$.

Warunki dzierżawy regulował kontrakt zawierany najczęściej na okres od kilku do nawet 40 lat ${ }^{91}$. Właściciel młyna mógł również wydzierżawić go dożywotnio i tak było w przypadku dwóch zachowanych kontraktów dzierżawnych z Piotrkowa. Młynarz Jakub Kula i jego żona Dorota, którzy w 1615 r. wydzierżawili młyn Bugaj, otrzymali prawo dożywotniego gospodarowania, a prawo to wygasało jedynie w przypadku, gdyby sami chcieli zakończyć dzierżawę ${ }^{92}$. Dzierżawca młyna słodowego, Stanisław Pszonka, otrzymał natomiast obwarowaną kontraktem obietnicę, że nie zostanie z niego usunięty do śmierci ${ }^{93}$.

W rzeczywistości dzierżawa trwała zwykle kilka lat. Wiadomo, że Pszonka był dzierżawcą młyna jeszcze w roku $1628^{94}$, ale w 1633 w źródłach występuje już nowy najemca — Andrzej Niewiadomy ${ }^{95}$. Pszonka młyn słodowy musiał więc opuścić między rokiem 1628 a 1633 . Zachowane źródła wskazują na dość częstą rotację dzierżawców. Na przykład w 1667 r. dzierżawcą młyna wójtowskiego był Jan Sempokowski, ale już w 1672 r. w tej roli wymieniany jest młynarz Marcin Głębowicz ${ }^{96}$. Nie wiadomo, jak długo Głębowicz piastował to stanowisko, ale w 1683 r. dzierżawcą był już Adam Frankowicz, z kolei w roku 1687 źródła odnotowały kolejnego najemcę - Marcina Stonkowicza ${ }^{97}$. Ten użytkował młyn wójtowski maksymalnie ok.

85 BCz, sygn. 590 Perg.

${ }^{86}$ SRP XII, s. 263 i n.

${ }^{87}$ AGAD, MK, sygn. 160, k. 101.

${ }^{88}$ AGAD, MK, sygn. 171, k. 132v.

${ }^{89}$ AGAD, MK, sygn. 171, k. 132v.

90 AGAD, MK, sygn. 160, k. 101.

91 Rzepkowski K. 2015, s. 138.

92 Rzepkowski K. 2015, s. 138.

93 AGAD, MK, sygn. 171, k. 133.

94 Lustracja. 1969, s. 24.

95 AAŁ, AMPPT, sygn. 71, Księga ochrzczonych 1627-1635, 1643, k. 103.

96 AAŁ, AMPPT, sygn. 71, Księga ochrzczonych 1653-1675, k. 150, 209.

97 AAŁ, AMPPT, sygn. 71, Księga ochrzczonych 1676-1700, s. 112, 168. 
5 lat, gdyż w 1692 r. gospodarował tu już kolejny najemca — bliżej nieznany Albert ${ }^{98}$. Oczywiście zdarzały się również przypadki dzierżawy jednego młyna przez dłuższy czas. Na przykład młynarz Jan Bugajski prowadził działalność we młynie bugajskim (od którego, jak widać, przyjął nazwisko) najpóźniej od 1644 do co najmniej 1656 r. ${ }^{99}$, zaś Adam Zarzecki dzierżawił ten sam młyn w latach $1680-1691$, a więc przez minimum 11 lat ${ }^{100}$. Inny z piotrkowskich młynarzy - Grzegorz Sieradzki jest po raz pierwszy wzmiankowany jako dzierżawca młyna słodowego w 1710 r., po raz ostatni zaś w 1720 r. ${ }^{101}$ Młynem tym zarządzał maksymalnie do roku 1724, gdy w źródłach odnotowano jego następcę, którym był Szymon Borkowski ${ }^{102}$. Sieradzki wydzierżawił młyn słodowy ponownie między rokiem 1732 a 1738 , nie wiadomo jednak na jak długo ${ }^{103}$.

Dzierżawa nakładała na młynarza szereg obowiązków, m.in. kosztownej konserwacji i naprawy młyna ${ }^{104}$. W kontrakcie zawartym w $1615 \mathrm{r}$. między starostą piotrkowskim a młynarzem Jakubem Kulą zapisano, że powinien on wraz z żoną „kamienie młyńskie, takze łoie, y insze naczenia, y potrzeby poprawę budowania swym kosztem odprawować powinni zeby zadne spustoszenie przesz nie w tym młynie nie było" 105 . Ponadto Kula zobowiązany był do naprawy grobli, upustu i podgródek ${ }^{106}$. Podobne obowiązki zostały zapisane w kontrakcie dzierżawy młyna słodowego z 1623 r. Stanisław Pszonka miał zreperować groblę, zbudować nowe podgródki i upusty, usunąć szlam ze stawu oraz dokonać ogólnej konserwacji młyna ${ }^{107}$. Były to znaczne wydatki, które zazwyczaj były pokrywane przez młynarza, niekiedy przy niewielkim wsparciu właściciela młyna. Zgodnie z zapisami kontraktu, starosta piotrkowski miał wspomóc Jakuba Kulę w naprawach, gwarantując siłę roboczą ${ }^{108}$. Z kontraktu, który starosta zawarł ze Stanisławem Pszonką wynika, że przed 1623 r. starostowie piotrkowscy wyznaczali dla młynarzy dzierżawiących młyn słodowy dodatek pieniężny w wysokości 70 grzywien przeznaczony na pokrycie kosztów konserwacji i niezbędnych napraw ${ }^{109}$. Dopłata ta została — jak czytamy w dokumencie — zlikwidowana przez Zygmunta Gonzagę Myszkowskiego. Dostojnik ten pełnił krótko urząd starosty piotrkowskiego (od 1588 r.), zatem to wtedy kwota musiała zostać zniesiona. Postanowienie Myszkowskiego podtrzymał również Maksymilian Przerębski — bezpośredni poprzednik Albrechta Starołęskiego na urzędzie starościńskim ${ }^{110}$. Nowy starosta ze względu na fatalny stan młyna słodowego postanowił przywrócić zlikwidowany przez jego poprzedników dodatek pieniężny, a nawet powiększyć go o 20 grzywien ${ }^{111}$.

Konieczność napraw i konserwacji była najcięższym obowiązkiem młynarzy; niektórzy nie byli w stanie się z niego wywiązać. $Z$ odpowiednim utrzymaniem młyna bugajskiego nie poradził sobie Jan Błuszczyk, dzierżawiący go przed rokiem 1615 ${ }^{112}$, a także dzierżawiąca młyn

98 AAŁ, AMPPT, sygn. 71, Księga ochrzczonych 1676-1700, s. 245.

99 AAŁ, AMPPT, sygn. 71, Księga ochrzczonych 1644-1652, k. 14, 61v, 92, 122; AAŁ, AMPPT, sygn. 71, Księga ochrzczonych 1653-1675, k. 14v, 33v.

100 AAŁ, AMPPT, sygn. 71, Księga ochrzczonych 1676-1700, k. 67, 100, 179, 231.

101 WBPŁ, AUSCPPT, rkps LXXV/35, s. 151, 185, 271, 297.

102 AAŁ, AMPPT, sygn. 72, Księga ochrzczonych 1721-1748, k. 22.

103 AAŁ, AMPPT, sygn. 72, Księga ochrzczonych 1721-1748, k. 89v, 126v.

104 Baranowski B. 1977, s. 24.

105 AGAD, MK, sygn. 160, k. 101v.

106 AGAD, MK, sygn. 160, k. 101v.

107 AGAD, MK, sygn. 171, k. 132v.

108 AGAD, MK, sygn. 160, k. 101v.

109 AGAD, MK, sygn. 171, k. 132v.

${ }^{110}$ AGAD, MK, sygn. 171, k. 132v.

111 AGAD, MK, sygn. 171, k. 132v.

112 AGAD, MK, sygn. 160, k. 101. 
słodowy młynarka, Anna Kuczkowska ${ }^{113}$. Sumy, które należało wyłożyć na naprawę młyna, były zapewne jednym z głównych powodów bardzo krótkiego użytkowania poszczególnych obiektów. W 1778 r. dzierżawcą młyna słodowego był Wojciech Foziński ${ }^{114}$. Najpewniej jeszcze w tym samym roku lub najpóźniej na początku 1779 r. najemcą został Andrzej Klimkowski, który gospodarował w nim zaledwie kilka miesięcy, zastąpiony w połowie tego samego roku przez młynarza Antoniego Gosławskiego ${ }^{115}$. Ten dzierżawił młyn najdłużej do 1782 r., gdy zarejestrowano jego następcę, Michała Palmowskiego ${ }^{116}$. I ten młynarz pracował w młynie słodowym krótko, gdyż pod koniec roku jako dzierżawca występuje już Dominik Kardyna ${ }^{117}$.

Duża rotacja wśród dzierżawców była również spowodowana poszukiwaniem przez nich lepszych ofert najmu. Jakub Kula przed objęciem w dzierżawę młyna bugajskiego był najemcą młyna w pobliskim Przygłowie, ale zapewne ze względu na dużo korzystniejsze warunki oferowane przez starostę piotrkowskiego postanowił opuścić Przygłów ${ }^{118}$.

Do najważniejszych obowiązków młynarza należał oczywiście przemiał zboża i śrutowanie słodu. Kontrakty dzierżawne zobowiązywały najemców do darmowego przemiału zbóż pochodzących z pól uprawnych właściciela młyna ${ }^{119}$. W młynie bugajskim młynarz otrzymywał $\mathrm{z}$ tego tytułu wynagrodzenie $\mathrm{w}$ postaci $1 / 3$ miary ${ }^{120}$. Takiego przywileju nie mieli natomiast młynarze dzierżawiący młyn słodowy. Jak zapisano w lustracji starostwa piotrkowskiego z lat 1564-1565: „młynarz od żadnych słodów, chocia je tam mielą, miary nie bierze, tylko dwór"121. Nie wiadomo, w jaki sposób kwestia ta była uregulowana w innych działających w Piotrkowie młynach, np. w młynie wójtowskim.

Poza przemiałem zboża, młynarze byli również bardzo często zobowiązani do hodowli określonej przez właściciela młyna liczby wieprzy ${ }^{122}$. Taki obowiązek został nałożony na dzierżawców młyna bugajskiego. W połowie lat sześćdziesiątych XVI w. młynarz był zobligowany do wykarmienia dwóch wieprzy ${ }^{123}$, zaś w 1569 r. czterech ${ }^{124}$. Młynarz mógł to obciążenie zamienić na rentę pieniężną, którą płacił staroście. Zgodnie z postanowieniami wyżej wymienionych lustracji wynosiła ona odpowiednio 2 i 4 floreny ${ }^{125}$. Młynarze dzierżawcy raczej decydowali się na uiszczanie należności w pieniądzu, niż prowadznie hodowli. Wiadomo, że wieprze były utrzymywane przez młynarza Jana Błuszczyka, ale już kolejny, Jakub Kula, płacił staroście rentę w wysokości 20 złotych na rok $^{126}$. Podobnie postępowali jego następcy. O oddawaniu staroście tego świadczenia w gotówce wspominają lustracje z lat 1628 i $1661^{127}$.

Za dzierżawę młynarz płacił właścicielowi młyna czynsz, którego wysokość określana była w zawartym między nimi kontrakcie. Na temat wysokości tych opłat w piotrkowskich młynach zachowało się kilka wzmianek. Najwięcej informacji dotyczy wysokości czynszu uiszczanego przez dzierżawców młyna bugajskiego. W latach 1564-1565 wynosił on 39 florenów

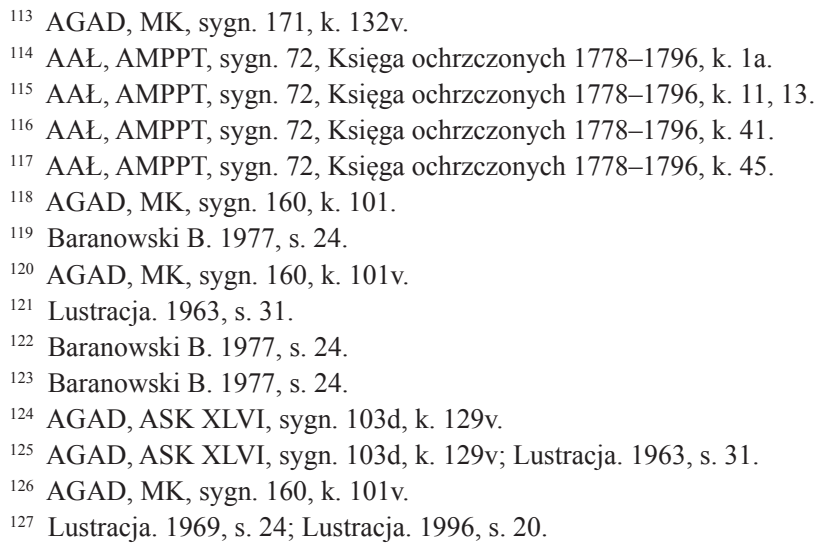


rocznie $^{128}$, zaś w 1569 r. 60 florenów ${ }^{129}$. Na nieco innych warunkach młyn został wydzierżawiony w 1615 r. Jakubowi Kuli. Ponieważ młyn znajdował się w bardzo złym stanie, starosta piotrkowski odstąpił od pobierania rocznego czynszu, przyjmując od Kuli ogólną opłatę za dzierżawę w wysokości 356 złotych $^{130}$. W kontrakcie zapisano również, że w przypadku rezygnacji przez Kulę z prawa do dzierżawy, jego następca miał uiścić sumę, którą Kula zapłacił staroście oraz wypłacić specjalny dodatek, jeżeli Kula podczas swojego zarządzania młynem wzniósłby jakieś budynki ${ }^{131}$. Podobny zapis zamieszczono też w akcie dzierżawy młyna słodowego z 1623 r., zgodnie z którym młynarz Stanisław Pszonka miał użytkować obiekt dożywotnio lub do czasu zwrócenia mu funduszy, które włożył w renowację mocno zniszczonego obiektu $^{132}$. W kolejnych latach powrócono do normalnej praktyki regulowania rocznego czynszu. W 1628 r. wynosił on, wliczając opłatę za odstąpienie od karmienia wieprzy, 200 florenów ${ }^{133}$.

Kolejne informacje o wysokości czynszu za dzierżawę młyna bugajskiego pochodzą dopiero z drugiej połowy XVIII w. W $1765 \mathrm{r}$. wynosił on 400 florenów rocznie ${ }^{134}$, zaś w $1789 \mathrm{r}$. 300 florenów ${ }^{135}$. W przypadku młyna słodowego dysponujemy danymi o wartości czynszu jedynie dla drugiej połowy XVI i pierwszej połowy XVII w. Według szesnastowiecznych lustracji starostwa piotrkowskiego, młynarz odprowadzał za jego dzierżawę roczny czynsz w wysokości 16 florenów ${ }^{136}$. Takie same należności odnotowane zostały w akcie dzierżawy z $1623 \mathrm{r}^{137}$ oraz lustracji z 1628 r. $^{138}$

Poza dwoma młynami królewskimi zachowały się wzmianki z XVIII w. dotyczące czynszu płaconego za dzierżawę młyna Kleszcz, młyna wójtowskiego oraz młynów wiatrakowych. W roku 1789 za użytkowanie Kleszcza należało uiścić 150 florenów rocznie, zaś młynów wiatrakowych 75 florenów. Za korzystanie z młyna wójtowskiego dzierżawiący go młynarz płacił 150 florenów $^{139}$.

Z przedstawionych powyżej warunków dzierżaw wynika, że młynarstwo było zajęciem dość kosztownym. Pomimo obciążeń, młynarze otrzymywali od właścicieli młynów rozległe przywileje, które przy dobrym zarządzaniu gwarantowały rentowność przedsięwzięcia. Na przykład wspomniany już wielokrotnie Jakub Kula otrzymał w 1615 r. od starosty piotrkowskiego w użytkowanie także usytuowane obok młyna łąki, ogrody i wszystkie przynależności, a także pola rolne, których areał — zgodnie z obietnicą starosty — miał być powiększony. Z przybytków tych młynarz musiał odprowadzać jedynie dziesięcinę ${ }^{140}$. Nic więc dziwnego, że właściciele młynów nie mieli problemów ze znalezieniem najemcy.

Zdarzało się, że niektórzy młynarze starali się obsadzać członkami swojej rodziny kilka młynów jednocześnie, tworząc swoiste „dynastie” młynarskie. W Piotrkowie do najbardziej znanych rodzin młynarzy należeli Kardynowie, prowadzący działalność przez niemal 50 lat. Rodzina ta pochodziła z podpiotrkowskiego Świerczowa, zajmując się młynarstwem być może już w ostatniej dekadzie XVII w. Jeden z przedstawicieli tej rodziny — Grzegorz przeniósł się

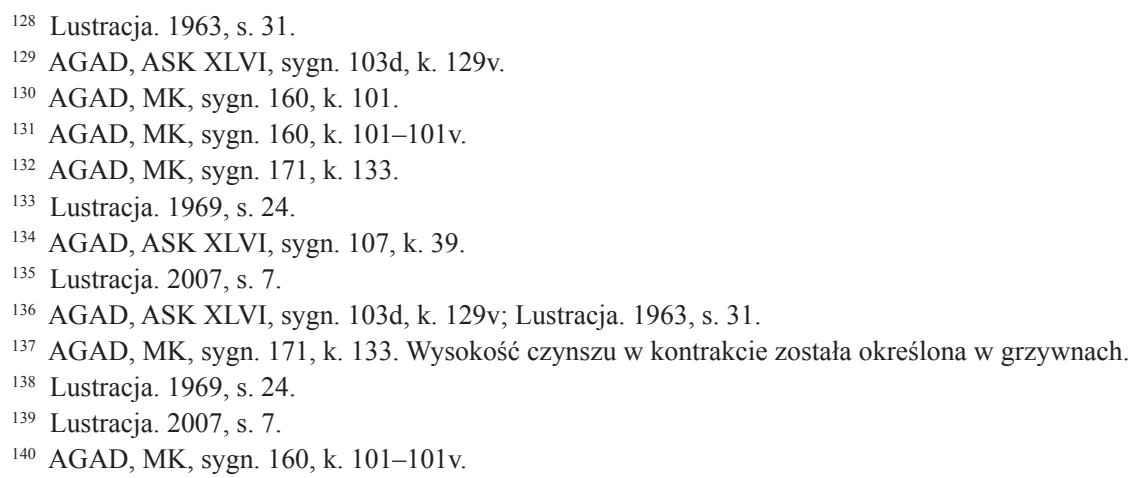


do Piotrkowa pomiędzy rokiem 1736 a 1738, wydzierżawiając młyn znajdujący się na Bugaju ${ }^{141}$. Mniej więcej w tym samym czasie spokrewniony z nim Ignacy, który w Piotrkowie osiadł między 1738 a 1740 r., został dzierżawcą młyna wójtowskiego ${ }^{142}$. Kardynowie mieli pod swoją pieczą także młyn Kleszcz w rodzinnym Świerczowie, który był dzierżawiony przez innego członka tej rodziny — Jakuba ${ }^{143}$. Po Jakubie wynajem tego młyna (najpóźniej w 1779 r.) obją jego syn, Józef Grzegorz ${ }^{144}$. Z kolei kuzyn świerczowskiego młynarza — Dominik wydzierżawił w roku 1782 młyn słodowy, który trzymał przez następne cztery lata ${ }^{145}$. W 1786 r. nowym gospodarzem tego obiektu został Józef Grzegorz, którzy przeniósł się ze Świerczowa ${ }^{146}$. Dominik natomiast w tym czasie zdecydował się na powrót do Świerczowa, gdzie najpewniej był młynarzem w Kleszczu ${ }^{147}$.

W źródłach pisanych dotyczących piotrkowskiego młynarstwa zwraca uwagę jeszcze jeden aspekt, a mianowicie duża rola kobiet w prowadzeniu tej działalności gospodarczej. Kontrakty dzierżawne były podpisywane przez właściciela nie tylko z młynarzem, ale również z jego żoną, która była pełnoprawną stroną umowy, ponosząc odpowiedzialność za wspólne wykonywanie zawodowych obowiązków. Kiedy Jan Błuszczyk doprowadził do poważnych zaniedbań w młynie bugajskim, to o ten stan rzeczy nie był oskarżany tylko on, ale również jego małżonka ${ }^{148}$. Również w umowie zawartej z następcą Błuszczyka, Jakubem Kulą, wszystkie klauzule odnoszą się zarówno do nowego młynarza, jak i do jego żony Doroty ${ }^{149}$. Co istotne, tak skonstruowany kontrakt dzierżawny miał swoje konsekwencje, ponieważ $\mathrm{w}$ razie śmierci młynarza-dzierżawcy pełnię obowiązków przejmowała pozostała po nim wdowa. W analizowanych źródłach zawarte są również wzmianki o samodzielnej dzierżawie obiektów przez kobiety. Przed 1623 r. młyn słodowy był prowadzony przez Annę Kuczkowską, zapewne wdowę po pierwotnym młynarzu-dzierżawcy ${ }^{150}$. Pod kobiecym zarządem znajdował się również przez pewien czas młyn bugajski. Gdy w 1661 r. do Piotrkowa przybyli urzędnicy królewscy, „,młynarka Ewa Powęcianka pokazała przywilej conservationis KJM teraźniejszego Jana Kazimierza PNM de data Cracoviae die 3 mensis Februarii 1649 konferowany, którym ich konserwują przy dzierżawieniu tego młyna spokojnym wespół z nieboszczykiem mężem jej, jako o tym sam przywilej szerzej opiewa"151.

Na podstawie wyrywkowych wzmianek trudno przedstawić pełną charakterystykę środowiska piotrkowskich młynarzy w XVI-XVIII w. Rozległe przywileje sprawiały zapewne, że podobnie jak w przypadku innych miejscowości młynarze cieszyli się dość wysokim statusem społecznym ${ }^{152}$. O ich znacznej pozycji świadczą utrzymywane przez nich kontakty ze szlachtą i bogatym mieszczaństwem. Niestety na podstawie uwzględnionych źródeł nie można określić pozycji zajmowanej przez młynarzy w społeczeństwie Piotrkowa. Księgi małżeństw parafii piotrkowskiej z XVII i XVIII w. nie zachowały się, zaś w księgach chrztów odnotowywano jedynie imiona żon młynarzy, stąd nie jest znane ich pochodzenie rodzinne.

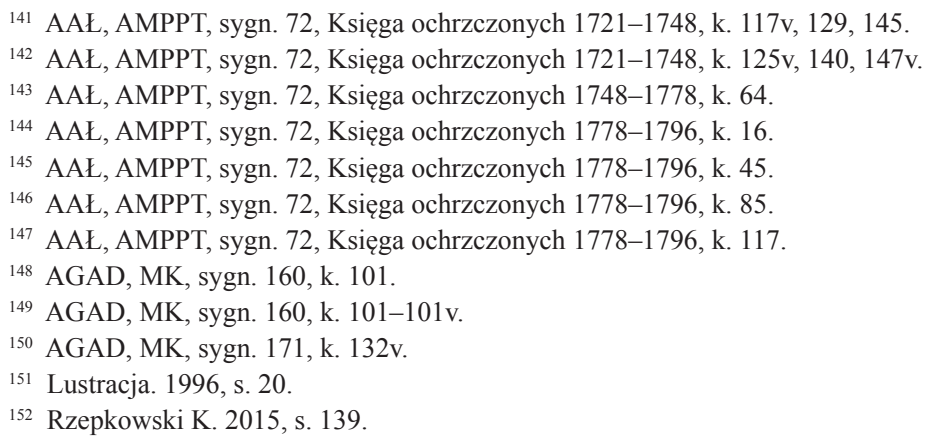




\section{Piekarstwo}

Gdy ziarno zostało zmielone we młynie na mąkę, można było przystąpić do wypieku chleba. W Piotrkowie chleb po raz pierwszy został wspomniany w przywileju wystawionym 16 października 1313 r. dla klasztoru cystersów w Sulejowie przez księcia Władysława Łokietka. Książę zezwolił w nim poddanym klasztornym na handel solą, chlebem, mięsem i wszelkimi innymi produktami w całym państwie, a w szczególności w Piotrkowie ${ }^{153}$. Ponieważ chleb był podstawowym produktem żywnościowym z pewnością mieszczanie piotrkowscy byli w niego zaopatrywani nie tylko przez piekarzy przyjeżdżających z sąsiednich miejscowości. Zapewne zatem już w czasie wydania książęcego przywileju dla poddanych sulejowskiego klasztoru, część mieszczan piotrkowskich trudniła się piekarskim rzemiosłem. Można zakładać, że z racji podstawowego znaczenia dla egzystencji, piekarstwo było jednym z najstarszych zajęć mieszkańców Piotrkowa, sięgającym być może czasów przedlokacyjnych. Pierwsze zachowane wzmianki o piotrkowskim piekarstwie pochodzą z aktu wykupu tamtejszego wójtostwa z 1420 r. Dokument ten, wyliczając należne wójtowi uposażenie, wymienia prawo pobierania czynszu z jatek rzemieślniczych, m.in. piekarskich. Co istotne, akt ten wzmiankuje, że prawo to przynależało wójtom „od dawna"154, zapewne więc zapis ten można łączyć z okresem lokacji miasta, a więc ostatnią dekadą XIII w. Być może również trzynastowieczną genezę miały dwa kramy piekarskie, które w Liber Beneficiorum Jana Łaskiego wymieniane są jako część uposażenia piotrkowskiego kościoła parafialnego. Możliwe, że kramy te zostały nadane farze w czasie erekcji świątyni, czyli w połowie wieku XIII. Pleban uzyskiwał z nich dochody, dzierżawiąc je miejscowym piekarzom, którzy z tego tytułu płacili czynsz w wysokości 6 groszy rocznie ${ }^{155}$.

Jakkolwiek nie jest znany najstarszy akt lokacyjny Piotrkowa, a co za tym idzie prawa i obowiązki jego mieszkańców, z pewnością mieli oni prawo do wypieku chleba na własny użytek. Według Henryka Rutkowskiego, przywilej ten powodował, że piekarze, którzy w Piotrkowie piekli chleb z przeznaczeniem na sprzedaż, musieli liczyć na przyjezdnych, którzy zatrzymywali się w mieście na jakiś czas lub przebywali w nim chwilowo ${ }^{156}$. Z opinią tą trudno się do końca zgodzić, ponieważ prawo do wypiekania chleba na własny użytek nie oznaczało, że wszyscy korzystali z tego przywileju. Dość liczne są wiadomości w źródłach z XVI-XVIII w., potwierdzające, że mieszczanie piotrkowscy także kupowali ten produkt. Najstarsza tego typu wzmianka została odnotowana w rejestrze wydatków piotrkowskiej Konfraterni Kupieckiej z 1544 r. ${ }^{157}$

W stuleciach XVI i XVII duży udział w piekarstwie piotrkowskim miały kobiety. Z pewnością odgrywały one główną rolę w wypieku chleba na własny użytek. Na tle stosunków panujących w ówczesnej Europie był to powszechny zwyczaj. Zaangażowanie kobiet w piekarstwo wynikało przede wszystkim z przypisywanej im roli społecznej, polegającej na zajmowaniu się gospodarstwem domowym. Jako że chleb był podstawowym produktem żywnościowym, naturalne było, że to kobieta-gospodyni dbała o to, aby go nie zabrakło. Podobnie zresztą było w przypadku zaopatrzenia staropolskiego domu w piwo ${ }^{158}$. Część kobiet uczestniczyła także w produkcji rzemieślniczej, choć nieliczne przekazy źródłowe nie pozwalają na dokładne omówienie tego problemu. $\mathrm{Z}$ pewnością białogłowy zaangażowane $\mathrm{w}$ ten rodzaj produkcji były

\footnotetext{
153 APPT, ZAKKiZW, sygn. 2, s. 27.

154 Rosin R. 1967, s. 27.

155 Łaski J. 1881, t. II, s. 222.

156 Rutkowski H. 1967, s. 54.

157 APPT, CKP, sygn. 55, s. 91.

158 Benneth J. 1996, s. 10 i 25.
} 
wdowami po zmarłych piekarzach lub prowadziły zakład wspólnie ze swoimi mężami. Ich sytuacja była zapewne analogiczna z sytuacją tutejszych browarniczek ${ }^{159}$.

O liczbie kobiet zaangażowanych w produkcję rzemieślniczą chleba informują lustracje starostwa piotrkowskiego. W latach $1564-1565$ było ich 25 , zaś 11 cztery lata później ${ }^{160}$. W pierwszej połowie XVII w. ich liczba nie przekraczała $12^{161}$.

Warunkiem prowadzenia sprzedaży chleba było odprowadzanie nakazanych prawem opłat — przede wszystkim czynszu za dzierżawienie kramów chlebowych. W XVI i XVII w. czynsz ten wynosił 6 groszy $^{162}$. Jak wielokrotnie już wspomniano, chleb był jednym z ważniejszych produktów żywnościowych. Jego istotne znaczenie podkreśla umiejscowienie kramów chlebowych w głównym punkcie miasta, czyli w rynku, tuż obok ratusza. Nie były one osobnymi budowlami, ale zostały ulokowane w dolnej kondygnacji jatek szewskich. Było ich łącznie 33, lecz nie ustalono, czy piekarze zawsze prowadzili sprzedaż we wszystkich z nich ${ }^{163}$.

Nie wiadomo, czy w ciągu XVI w. piotrkowscy piekarze podejmowali jakieś próby zrzeszenia się w cechu. $Z$ całą pewnością rozpoczęli takie działania w pierwszej połowie następnego stulecia. Wskazuje na to pismo odnalezione przez Michała Rawitę-Witanowskiego z 24 lutego 1630 r., które w imieniu króla do burmistrza i piotrkowskiej rady miejskiej wystosował kanclerz wielki koronny Jakub Zadzik. Na podstawie tego dokumentu badacz wysunął daleko idący wniosek o istnieniu już w tym czasie w Piotrkowie cechu zrzeszającego tutejszych piekarzy i piernikarzy ${ }^{164}$. Kolejni historycy zajmujący się dziejami i życiem wewnętrznym Piotrkowa w dobie staropolskiej hipotezę Witanowskiego pominęli. W moim przekonaniu jej znaczenie jest jednak duże. Tym bardziej, że publikacja pozostającej przez kilkadziesiąt lat w rękopisie pracy Michała Rawity-Witanowskiego przyczyniła się do rozpowszechniania tej tezy, która w powszechnej świadomości zaczyna funkcjonować jako niebudzący wątpliwości fakt historyczny. Tymczasem kwestia ta nie jest tak oczywista, jak przed laty wydawało się temu Autorowi. Oryginał dokumentu nie zachował się do naszych czasów, jednak jego treść została przytoczona przez Witanowskiego: „Uskarżali się przed nami Starsi Cechu Piekarskiego i Piernikarskiego Miasta naszego Piotrkowa, że wierności Wasze przywileju ich dla lepszego w Cechu tamecznym zachowania porządku, za pozwoleniem wprzód waszym u nas otrzymanego, do execuciej przywodzić nie chcecie, ani występnych względem thego karzecie. Czym isz Wierność Wasza themusz przywilejowi, gdy występni, którzy Starszych słuchać nie chcą, bez karania zostają — derogujecie. Przeto rozkazujemy Wierności W[aszym]. abyście pomieniony przywilej wcale zachowali, i on do execucii przywodzili, pilnie tego przestrzegając, jakoby nas o to skargi dalsze nie dochodziły"165.

W zapisie tym zawarte są dwie istotne informacje. Po pierwsze jasno z niego wynika, że piotrkowscy piekarze, najpewniej pod koniec lat dwudziestych XVII w., zaczęli podejmować starania o utworzenie własnego cechu, co zaowocowało spisaniem statutu i pozwoleniem królewskim na założenie piekarskiej organizacji cechowej. Po drugie, z kanclerskiego listu wynika, że pomimo początkowej akceptacji rajców miejskich, ostatecznie statut cechowy nie został przez nich zatwierdzony. W dosłownym sensie oznaczało to brak uznania cechu przez władze miejskie, co niosło za sobą określone konsekwencje prawne. Cechy rzemieślnicze stawały się

159 Majewski M.Ł. 2019, s. 55. Wskazują na to rejestry czopowego, np. według rejestru czopowego z 1552/ 1553 r. kobiety stanowiły co najmniej 18,3\% wszystkich browarników.

${ }^{160}$ Lustracja. 1963, s. 29; AGAD, ASK XLVI, sygn. 103d, k. 128v.

161 Lustracja. 1969, s. 22.

162 Lustracja. 1963, s. 29; AGAD, ASK XLVI, sygn. 103d, k. 128v; Lustracja. 1969, s. 22.

163 APPT, CS, sygn. 59.

164 Rawita-Witanowski M. 2017, s. 741 i n.

165 Rawita-Witanowski M. 2017, s. 742. 
bowiem pełnoprawną częścią życia miejskiego dopiero w chwili zatwierdzenia statutu cechowego przez urzędników municypalnych, następnie zaś potwierdzenia przez burmistrza elekcji cechmistrzów i subdelegatów cechowych, które następowało po złożeniu przez nich przysięgi na ratuszu. Brak akceptacji ze strony magistratu sprawiał, że władze cechowe, podejmowane przez nie decyzje oraz ferowane wyroki sądowe nie były uznawane. Bez zatwierdzenia przez radę miejską zrzeszenie się piotrkowskich piekarzy w cech nie miało większego znaczenia. Proces powstawania niemal każdej organizacji cechowej miał charakter oddolny. W pierwszej kolejności to reprezentanci danego rzemiosła wyrażali chęć zrzeszenia się w cechu, który lepiej chroniłby ich prawa. Cech nie powstawał jednak w chwili zawiązania związku przez rzemieślników, ale w momencie zatwierdzenia statutu i władz cechowych przez monarchę i władze miejskie. Na przykład piotrkowscy piwowarzy zrzeszyli się w cech w 1721 r., ale dopiero w 1722 r., po zatwierdzeniu statutu organizacji przez króla i uznaniu cechu przez władze miejskie rozpoczął on funkcjonowanie ${ }^{166}$. Tak było również w przypadku innych cechów rzemieślniczych działających w Piotrkowie.

Z powodu braku odpowiednich przekazów, można jedynie hipotecznie rozważać przyczyny, które pod koniec lat dwudziestych XVII w. skłoniły piotrkowskich piekarzy do zawiązania cechu, oraz powody, dla których próba ta była niepomyślna. Dążenie piekarzy do zrzeszenia się we własnej organizacji zawodowej mogło wynikać z kryzysu, który dotknął w tym czasie miasto, a którego powodem było m.in. morowe powietrze ${ }^{167}$. W takich okolicznościach mieszczanie szukali różnych sposobów na osiągnięcie stabilizacji i zabezpieczenie swoich interesów. Ustanowienie cechu przez piekarzy mogło pomóc w ograniczeniu konkurencji przyjezdnych handlarzy chlebem oraz w konsekwencji doprowadzić do przyznania tym pierwszym monopolu na handel pieczywem. Dokładnie w tym samym czasie starania o założenie własnego cechu podjęli piotrkowscy piwowarzy, mocno dotknięci skutkami zarazy oraz konkurencją piwowarów starościńskich. I w tym przypadku próba założenia cechu zakończyła się niepowodzeniem ${ }^{168}$.

Zapisy źródłowe nie wskazują na przyczyny tych porażek. Najbardziej prawdopodobne wydają się protesty mieszczan, którzy obawiali się zmonopolizowania produkcji dwóch najważniejszych artykułów żywnościowych. Niezadowolenie społeczne i opór mieszkańców wobec projektów utworzenia cechu piekarskiego mogą uzasadniać wycofanie poparcia burmistrza i piotrkowskich rajców dla tego projektu. Michał Rawita-Witanowski uważał jednak, że cech piekarski mimo to został zatwierdzony, a dowodem na to miało być, według niego, pominięcie w lustracji Piotrkowa z 1661 r. informacji o liczbie działających w mieście piekarzy ${ }^{169}$. Teza ta jest jednak nieprzekonująca, ponieważ w czasie spisywania siedemnasto- i osiemnastowiecznych lustracji przed urzędnikami królewskimi swoje przywileje prezentowały wszystkie działające w mieście cechy rzemieślnicze. Gdyby teza Witanowskiego była słuszna, swoje uprawnienia okazałby też cech piekarski, tymczasem nie został on wymieniony wśród innych organizacji zawodowych istniejących w Piotrkowie w $1661 \mathrm{r}$. Opinia badacza jakoby cech nie został uwzględniony, ponieważ jego przywilej zaginął w tym czasie ${ }^{170}$, również nie przekonuje. W takim przypadku zapewne piekarze złożyliby przed królewskimi urzędnikami stosowne opowiedzenie, starając się jednocześnie u króla o odnowienie cechowego przywileju. Taka sytuacja nie miała jednak miejsca. Spór między władzami miasta a piekarzami, którego świadectwem jest list z lutego 1630 r., zakończył się niepowodzeniem piekarzy. Dopiero w 1749 r. tej grupie zawodowej udało się powołać do życia własny cech. Chociaż, jak się wydaje, także

\footnotetext{
166 Majewski M.Ł. 2019, s. 126.

167 Lustracja. 1969, s. 11.

168 Lustracja. 1969, s. 19.

169 Rawita-Witanowski M. 2017, s. 742.

170 Rawita-Witanowski M. 2017, s. 742.
} 
i wtedy nie uniknięto pewnych kontrowersji i sporów, gdyż pierwsi cechmistrzowie zostali zatwierdzeni przez piotrkowskie władze dopiero dwa lata później, zaś pierwsza schadzka cechowa odbyła się w grudniu 1752 r. ${ }^{171}$

O środowisku piotrkowskich piekarzy praktycznie brak informacji. W źródłach z XVII w. odnalazłem nazwisko zaledwie jednego piekarza - Adama Trzcińskiego, wzmiankowanego pod rokiem $1663 \mathrm{w}$ księdze ochrzczonych piotrkowskiej fary ${ }^{172}$. Michał Rawita-Witanowski, który bardzo pobieżnie korzystał z niezachowanych dziś osiemnastowiecznych ksiąg cechu piekarskiego, wymienił nazwiska sześciu piekarzy: Stefana Millnera (właściwie Millera) oraz Stanisława Podgóralskiego — pierwszych cechmistrzów, czeladnika Jana Koszabę (który piekąc chleb przypadkiem zapiekł w nim żabę) oraz Szymona Skortyńskiego, Jakuba Wichmana i bliżej nieznanego Świętcichowskiego ${ }^{173}$. O tym ostatnim oraz Koszabie nie zachowały się żadne bliższe dane. Pierwsza wzmianka o Stefanie Millerze pochodzi z 29 stycznia 1749 r., gdy wraz z żoną Anną ochrzcił w piotrkowskim kościele parafialnym swojego pierworodnego syna, Jana Chryzostoma ${ }^{174}$. Stefan owdowiał przed rokiem 1766 i zawarł ponowny związek małżeński z bliżej nieznaną Marianną, która urodziła mu córkę Mariannę oraz syna Jana ${ }^{175}$. Stefan musiał mieć ugruntowaną pozycję wśród piotrkowskiego pospólstwa, na co wskazuje pełnienie przez niego w latach sześćdziesiątych XVIII w. funkcji trybuna w radzie dwunastu mężów ${ }^{176}$. Równie znaczną pozycję musiał mieć wicestarszy cechu piekarskiego, Stanisław Podgóralski, żonaty z Agnieszką, którego dzieci do chrztu podawali przedstawiciele znaczących i bogatych rodów patrycjuszowskich: Kurowskich, Pieściochów i Watsonów ${ }^{177}$. Jakuba Wichmana wzmiankują akta metrykalne z lat 1784-1794. Wiadomo, że był żonaty z Agnieszką, z którą doczekał się czterech synów i jednej córki. Utrzymywał bliskie kontakty z tutejszym patrycjatem, zwłaszcza z rodziną Matusewiczów ${ }^{178}$. Jego najmłodszego syna podawał do chrztu burmistrz piotrkowski, Antoni Vicini ${ }^{179}$. Również z księgi chrztów pochodzi jedyna znana mi wzmianka o Szymonie Skortyńskim, żonatym z Jadwigą, która w 1784 roku urodziła mu córkę Zofię ${ }^{180}$.

Niewiele więcej wzmianek zachowało się na temat piotrkowskich piernikarzy. Rzemieślnicy zajmujący się w Piotrkowie wypiekiem tego przysmaku są po raz pierwszy wzmiankowani w źródłach z lat osiemdziesiątych XVI stulecia. Pierwszy znany nam piotrkowski piernikarz — Mikołaj działał w mieście co najmniej od roku $1585^{181}$. W 1589 r. w źródłach zarejestrowano piernikarza Jakuba oraz innego mieszczanina trudniącego się tym rzemiosłem, nie notując jego imienia ${ }^{182}$. Kilku piernikarzy odnotowują również źródła z pierwszej połowy XVII w. Dnia 24 września 1627 r. wikariusz kościoła parafialnego, Albert Cichonkowicz, ochrzcił pierworodnego syna piernikarza Stanisława i jego żony Heleny ${ }^{183}$. Małżonka Stanisława zmarła najprawdopodobniej wkrótce po porodzie, Stanisław zaś ożenił się powtórnie z bliżej nieznaną Zofią, z którą doczekał się syna Jana ${ }^{184}$. W 1634 r. pożyczył w piotrkowskiej Konfraterni Kupieckiej

\footnotetext{
171 Rawita-Witanowski M. 2017, s. 742.

172 AAŁ, AMPPT, sygn. 71, Księga ochrzczonych 1653-1675, k. 111v.

173 Rawita-Witanowski M. 2017, s. 742 i n.

174 AAŁ, AMPPT, sygn. 72, Księga ochrzczonych 1748-1778, s. 7.

175 AAŁ, AMPPT, sygn. 72, Księga ochrzczonych 1748-1778, s. 235, 260.

176 AAŁ, AMPPT, sygn. 72, Księga ochrzczonych 1748-1778, s. 235, 260.

177 AAŁ, AMPPT, sygn. 72, Księga ochrzczonych 1748-1778, s. 25, 105, 129, 144.

178 AAŁ, AMPPT, sygn. 72, Księga ochrzczonych 1778-1796, s. 74, 97, 107, 156.

179 AAŁ, AMPPT, sygn. 72, Księga ochrzczonych 1778-1796, s. 184.

180 AAŁ, AMPPT, sygn. 72, Księga ochrzczonych 1778-1796, s. 62.

181 APPT, CKP, sygn. 57, s. 4.

182 APPT, CKP, sygn. 57, s. 34, 50.

183 AAŁ, AMPPT, sygn. 71, Księga ochrzczonych 1626-1635, 1643, k. 15.

184 AAŁ, AMPPT, sygn. 71, Księga ochrzczonych 1626-1635, 1643, k. 73.
} 
30 florenów, nie wiadomo jednak, do czego posłużyła ta pożyczka ${ }^{185}$. U piotrkowskich kupców zaciągnął dług również piernikarz Jan Prusowicz. W 1631 r. uzyskał pożyczkę w wysokości 150 florenów, zastawiając półtora czerwonych portugałów, 14 pierścieni, 6 srebrnych guzów, srebrny pas, zankle z łańcuszkiem oraz pas złocisty ${ }^{186}$. Rok później poza zanklami, dziesięcioma pierścieniami, pięcioma srebrnymi guzami oraz pasem, zastawił także 10 srebrnych łyżek, za co ponownie uzyskał gotówkę w wysokości 150 florenów ${ }^{187}$. Zarówno wysokość pożyczki, jak i przedmioty pod zastaw świadczą o znacznej zamożności Prusowicza, oraz o szerokiej skali podejmowanych przez niego operacji handlowych. Żonaty był z nieznaną z nazwiska Jadwigą, która w 1633 r. urodziła mu córkę Zofię ${ }^{188}$. Gorzej powodziło się innemu piernikarzowi - Marcinowi Abrahamowiczowi. Osiadł w Piotrkowie w pierwszej połowie lat trzydziestych XVII stulecia, zamieszkując początkowo na tzw. Kramnicach położonych poza murami miejskimi. Najpewniej nie miał zbyt dużych dochodów, skoro uzależniony był od niewielkich, acz ciągłych pożyczek ${ }^{189}$. W księdze chrztów piotrkowskiej fary w latach 1632-1656 wzmiankowani są ponadto jeszcze trzej piernikarze: Albert zwany Łamduek, Walenty oraz Jan ${ }^{190}$. Poza wpisami do metryki na ich temat nie zachowały się inne informacje.

\section{Ceny chleba w Piotrkowie w XVI-XVIII wieku}

Kwestia cen w staropolskim Piotrkowie pozostaje jednym z najsłabiej rozpoznanych zagadnień; niewątpliwie ma na to wpływ niewystarczająca liczba źródeł ${ }^{191}$. Ich niewielki zasób czyni niemożliwym opracowanie wykazu cen poszczególnych produktów dostępnych w miejskiej ofercie w XVI-XVIII w., jak miało to miejsce dla dużych ośrodków dawnej Rzeczpospolitej ${ }^{192}$.

Precyzyjne ustalenie cen chleba w Piotrkowie w okresie nowożytnym utrudnia przede wszystkim charakter wzmianek. Expensy wpisywane do ksiąg cechowych często zawierają łączną kwotę zapłaconą za kilka produktów. Na przykład w rejestrze wydatków piotrkowskiej Konfraterni Kupieckiej z 1546 r. odnotowano, że kupcy zapłacili 9 groszy za mięsa, chleby i piwo ${ }^{193}$. Podobnie w dwóch zapiskach z 1594 r. chleb został wymieniony łącznie z innymi artykułami (korzeniami, octem, masłem i jajkami) ${ }^{194}$. Taki sam sposób ewidencji zastosowano też później.

185 APPT, CKP, sygn. 31, s. 22.

186 APPT, CKP, sygn. 31, s. 2.

187 APPT, CKP, sygn. 31, s. 7.

188 AAŁ, AMPPT, sygn. 71, Księga ochrzczonych 1626-1635, 1643, k. 78.

189 Majewski M.Ł. 2017, s. 78 i n. Marcin Abrahamowicz był, obok Zachariasza Antoniewicza, pierwszym poświadczonym przez źródła Ormianinem osiadłym w Piotrkowie. W latach 1634-1639 Abrahamowicz zaciągał regularnie pożyczki w wysokości 20 florenów rocznie. W przeciwieństwie do innych kupców sam rzadko pożyczał pieniądze lub udzielał rękojmi innym kupcom. Wyjątkiem były poręczenia za Zygmunta Kruczkowicza, których Abrahamowicz udzielał na zasadzie wzajemności, ponieważ Kruczkowicz sam często poręczał za ormiańskiego piernikarza, umożliwiając mu tym samym zaciąganie kolejnych pożyczek, zob.: APPT, CKP, sygn. 31, s. 23, 28, 38, 48, 57, 63; Majewski M.Ł. 2017, s. 77, 79.

190 AAŁ, AMPPT, sygn. 71, Księga ochrzczonych 1626-1635, 1643, k. 77v, 117v; AAŁ, AMPPT, sygn. 71, Księga ochrzczonych 1653-1675, k. 33v.

191 Pierwszej próby oszacowania cen w staropolskim Piotrkowie podjął się Tomasz Kruz. Przedmiotem jego badań były ceny sprzedawanego w Piotrkowie w XVII i XVIII w. alkoholu: piwa, wina, miodu i gorzałki, zob.: Kruz T. 2008, s. 89-103. Najnowsze opracowanie dotyczące piwowarstwa piotrkowskiego w XVI-XVIII w. wykazało liczne błędy w przygotowywanych przez Kruza zestawieniach dotyczących cen piwa, a porównanie wykazów tabelarycznych z zapisami źródłowymi pozwala poddać w wątpliwość także określone przez badacza ceny innych alkoholi, zob.: Majewski M.Ł. 2019, s. 110-124.

192 Opracowań cen doczekały się m.in. Kraków (Tomaszewski E. 1934; Pelc J. 1935), Lwów (Hoszowski S. 1928; Hoszowski S. 1934), Warszawa (Adamczyk W. 1938), Lublin (Adamczyk W. 1935) i Gdańsk (Furtak T. 1935; Pelc J. 1937).

193 APPT, CKP, sygn. 55, s. 91.

194 APPT, CKP, sygn. 57, s. 91 i n. 
Na przykład w rejestrze wpływów i wydatków piotrkowskiej Konfraterni Kupieckiej z lat 1670-1731 wydatki na chleb przeważnie umieszczano łącznie z wydatkami na pierniki.

Kolejnym problemem jest często brak określenia ilości kupowanego chleba. Najbardziej precyzyjne są expensy z lat 1744-1751, podające liczbę bochenków. Natomiast spisywane po łacinie rejestry wydatków Konfraterni Kupieckiej z lat 1544-1551, choć nie zawierają takich precyzyjnych informacji, pozwalają ustalić cenę za jeden bochenek, ponieważ gdy kupowano większą ich ilość stosowano liczbę mnogą. W rejestrach z późniejszych lat XVI oraz XVII w. sporządzanych w języku polskim takiego rozróżnienia nie praktykowano. W zachowanych spisach nie umieszczono też żadnych danych na temat masy chlebowych bochnów; rzadko wskazywano rodzaj nabywanego chleba.

Wydatki Konfraterni Kupieckiej i cechu rzeźniczego wskazują, że cena chleba w Piotrkowie utrzymywała się na stałym poziomie, najpewniej jednak zmieniała się jego masa. Pierwszy udokumentowany zapis o zakupie chleba w Piotrkowie został odnotowany w 1544 r. w tzw. księdze pieprzu. Nie jest znana ilość produktu, ale piotrkowscy kupcy nabyli więcej niż jeden bochenek, o czym świadczy użyty zwrot ad panibus. Za chleby te zapłacili 3 grosze ${ }^{195}$. Zapewne na stół piotrkowskich kupców trafiły wtedy trzy chleby, co poświadcza expensa z 1548 r., w której odnotowano zakup jednego bochenka chleba za 1 grosz ${ }^{196}$. Taka cena utrzymała się co najmniej do końca XVI w. W rejestrach kosztów piotrkowskiej Konfraterni Kupieckiej za lata 1588 i 1590 wspomniano o wyższej cenie chleba (w dwóch wzmiankach z 1588 r. odpowiednio 2 i 3 gr, w 1590 r. 2 gr) ${ }^{197}$. Identyczny koszt zanotowano w rejestrze wydatków cechu rzeźniczego $z$ lat 1552 i 1555 ( 2 gr $)^{198}$. Najpewniej nie były to ceny płacone za jeden bochenek, ale za większą ich ilość. Poświadczają to inne zestawienia $\mathrm{z}$ tego czasu, w tym jedno pochodzące z 1588 r. Wspomniano tam o chlebie po 1 gr za bochenek ${ }^{199}$. Podobną cenę tego towaru odnotowano z latach $1587,1594,1595$ oraz $1597^{200}$. Dzięki wzmiankom z lat 1588-1589 wiadomo, że piotrkowscy kupcy kupowali wyłącznie chleb biały ${ }^{201}$.

Nie wiadomo, jak kształtowały się ceny chleba w Piotrkowie przez większą część XVII w. Pierwsze dane z tego stulecia dotyczące zakupu pieczywa pochodzą z 1670 r., zaś chleba dopiero z 1676 r. ${ }^{202}$ Generalnie, w rejestrach wydatków z lat 1670-1731 wymieniano chleb niezwykle rzadko. Zdecydowanie częściej w tym czasie piotrkowscy kupcy wpisywali kupowany regularnie piernik. Warto jednak zaznaczyć, że posiłki członków Konfraterni miały charakter luksusowy. Trudno przyjąć, że w jadłospisie codziennym, nawet kupieckiej elity, pierniki górowały nad chlebem. Ta wątpliwość tym bardziej dotyczy innych grup społecznych. W wykazach z tego czasu często podawano łączną cenę kilku towarów, stąd chleb niejednokrotnie był szacowany razem z piernikiem. Na podstawie kilku wzmianek, gdy cena chleba została podana osobno, nie sposób ustalić koszt zakupu jednego bochenka. W rejestrach nie określano jego ilości. W 1682 r. na stół piotrkowskiej Konfraterni Kupieckiej trafił chleb, za który zapłacono 3 gr $^{203}$. Z kolei trzy lata później miejscowi kupcy kupili chleb do wódki za 6 gr, zaś w latach 1690 i 1692 zapłacili za niego $8 \mathrm{gr}^{204}$. Zanotowane w rejestrach sumy wskazują, że chleb był kupowany w większej ilości.

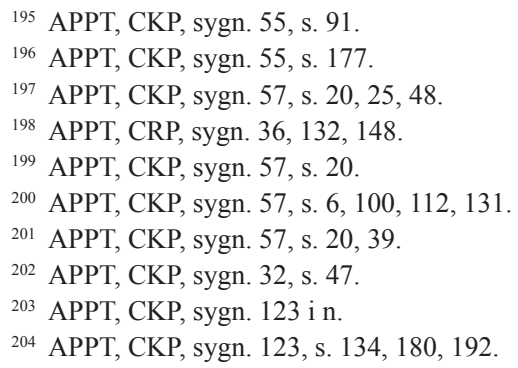


Być może cena za jeden bochenek białego chleba kształtowała się na takim samym poziomie jak w pierwszej połowie XVIII w. Pierwsze wzmianki o chlebie z tego stulecia zostały odnotowane w rejestrach $z$ lat 1729-1730, są to jednak dane bardzo ogólne ${ }^{205}$. Dopiero w niezwykle precyzyjnych spisach z lat 1744-1751 nadmieniono, poza wydaną sumą, również liczbę zakupionych bochenków. Dzięki temu wiadomo, że w tym czasie jeden bochenek chleba kosztował 3 gr $^{206}$. Inną wartość zanotowano jedynie w 1749 r., gdy piotrkowscy kupcy za 40 bochenków zapłacili 3 zł 6 gr zł, czyli jeden bochenek kosztował 2,4 gr ${ }^{207}$. Mógł to być inny rodzaj chleba, lub chleb o mniejszej masie. Z XVIII w. pochodzi jeszcze pięć wzmianek na ten temat. Nie są one już tak skrupulatne. W 1754 r. cenę chleba podano łącznie z wieloma innymi, zakupionymi produktami, natomiast rok później odnotowano zakup chleba na trzy dni za łączną sumę 4 zł $22 \mathrm{gr}^{208}$. W 1756 r. zapisano ogólnie wydatek 2 zł 6 gr na bliżej nieokreśloną ilość chleba ${ }^{209}$. Po raz ostatni koszt nabycia chleba odnotowano w rejestrze wydatków Konfraterni Kupieckiej z 1759 r. W tymże roku zakupu dokonano dwukrotnie, lecz ze względu na lakoniczność zapisów nie można określić, ile kosztował jeden bochenek ${ }^{210}$.

Poza chlebem w źródłach wspomniano też o innych rodzajach pieczywa, przede wszystkim o pierniku. Choć wzmianki o tym wypieku są dość liczne, trudno ustalić jego dokładną cenę, ponieważ nie sprecyzowano jego ilości. Za produkt ten piotrkowscy kupcy płacili między rokiem 1670 a 1692 od 3 do 22 gr $^{211}$. Zaopatrywali się w niego najpewniej u miejscowych wytwórców, choć nie jest też wykluczone, że niekiedy u przyjezdnych piernikarzy m.in. tych przybywających do Piotrkowa $\mathrm{z}$ Torunia ${ }^{212}$. Poza białym chlebem i piernikiem zachowane źródła wymieniają jeszcze jeden rodzaj pieczywa, a mianowicie obwarzanki. W 1692 r. ich bliżej nieokreśloną ilość za łączną kwotę 12 gr zakupili piotrkowscy kupcy ${ }^{213}$, zaś w 1697 r. 6 gr na ten przysmak wydali piotrkowscy rzeźnicy ${ }^{214}$.

Adres Autora:

dr Marcin Łukasz Majewski

Polska Akademia Umiejętności w Krakowie

ul. Sławkowska 17

31-016 Kraków

marmaj54@wp.pl

https://orcid.org/0000-0003-4483-6136

\section{BIBLIOGRAFIA}

\section{Źródla archiwalne}

AAŁ [Archiwum Archidiecezjalne w Łodzi], AMPPT [Akta Metrykalne Parafii Piotrków Trybunalski], sygn. 71,72 .

AGAD [Archiwum Główne Akt Dawnych], ASK I [Archiwum Skarbu Koronnego, dział I], sygn. $24,25,26,79$.

AGAD [Archiwum Główne Akt Dawnych], ASK XLVI [Archiwum Skarbu Koronnego, dział XLVI], sygn. $103 d, 107$.

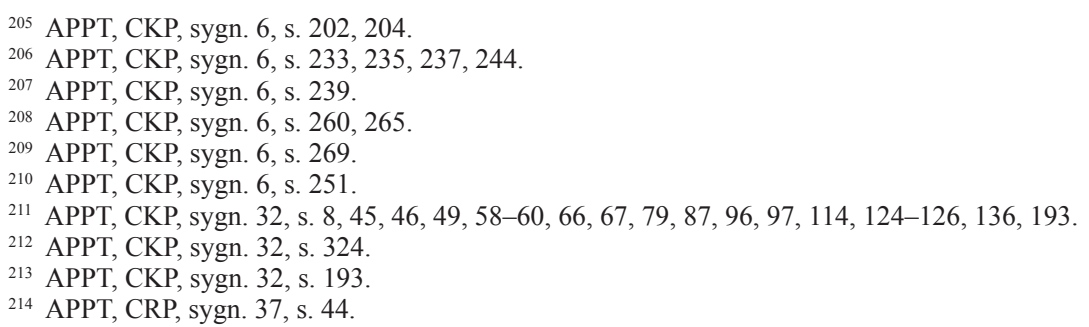


AGAD [Archiwum Główne Akt Dawnych], MK [Metryka Koronna], sygn. 23, 24, 160, 171.

APPT [Archiwum Państwowe w Piotrkowie Trybunalskim], CKP [Cech Kupców Piotrkowskich], sygn. 7, 31, 32, 56, 57.

APPT [Archiwum Państwowe w Piotrkowie Trybunalskim], CRP [Cech Rzeźników Piotrkowskich], sygn. 36, 37.

APPT [Archiwum Państwowe w Piotrkowie Trybunalskim], CS [Cech Szewski], sygn. 59.

APPT [Archiwum Państwowe w Piotrkowie Trybunalskim], ZAKKiZW [Zbiór Akt Kościelnych, Klasztornych i Związków Wyznaniowych], sygn. 2, 79.

$\mathrm{BCz}$ [Biblioteka Książąt Czartoryskich], sygn. 590 Perg.

WBPŁ [Wojewódzka Biblioteka Publiczna w Łodzi], AUSCPPT [Akta Urzędnika Stanu Cywilnego Parafii Piotrków Trybunalski], rkps LXXV/35.

\section{Źródła i opracowania publikowane}

Adamczyk Władysław. 1935. Ceny w Lublinie od XVI do końca XVIII wieku, Lwów.

Adamczyk Władysław. 1938. Ceny w Warszawie w XVI i XVII wieku, Lwów.

Anusik Zbigniew. 1989. Życie polityczne miasta w latach 1655-1793, [w:] Dzieje Piotrkowa Trybunalskiego, red. B. Baranowski, Łódź, s. 144-158.

Baranowski Bohdan. 1977. Polskie mlynarstwo, Wrocław.

Baranowski Bohdan. 1989. Stosunki gospodarcze i społeczne w drugiej połowie XVII i w XVIII wieku, [w:] Dzieje Piotrkowa Trybunalskiego, red. B. Baranowski, Łódź, s. 84-96.

Benneth Judith M. 1996. Ale, Beer and Brewers in England. Women's Work in a Changing World 1300-1600, New York-Oxford.

Czuba Anna, Gąsior Marcin, Kotewicz Ryszard. 1993. Przywileje miasta Piotrkowa przez królów polskich w wiekach XV, XVI, XVII i XVIII wystawione, Piotrków Trybunalski.

Dembińska Maria. 1973. Przetwórstwo zbożowe w Polsce średniowiecznej (X-XIV wiek), Warszawa.

Długokęcki Wiesław, Kuczyński Jan, Pospieszna Barbara. 2004. Młyny w Malborku i okolicy od XIII do XIX wieku, Malbork.

Furtak Tadeusz. 1935. Ceny w Gdańsku w latach 1701-1815, Lwów.

Gadocha Marcin. 2011. Cech piekarzy $i$ handel chlebem $w$ Krakowie w okresie nowożytnym, Kraków.

Głowacki Kazimierz. 1984. Urbanistyka Piotrkowa Trybunalskiego, Piotrków-Kielce.

Hoszowski Stanisław. 1928. Ceny we Lwowie w XVI i XVII wieku, Lwów.

Hoszowski Stanisław. 1934. Ceny we Lwowie w latach 1701-1914, Lwów.

Kizik Edmund. 2008. Młyny w Ekonomii Malborskiej wedtug inwentarzy z lat 1755 i 1765, „Kwartalnik Historii Kultury Materialnej”, R. LVI, nr 3-4, s. 397-404.

Kruz Tomasz. 2005. Browarnictwo w Piotrkowie od XVI do XVIII wieku, Grudziądz.

Kruz Tomasz. 2008. Ceny alkoholu w Piotrkowie od XVII do XVIII wieku, „Badania nad Dziejami Regionu Piotrkowskiego", z. 7, s. 89-103.

Kubicki Rafał. 2012. Mtynarstwo w państwie zakonu krzyżackiego w Prusach w XIII-XV w. (do 1454 r.), Gdańsk.

Lustracja. 1963. Lustracja województw wielkopolskich i kujawskich 1564-1565, cz. II, wyd. A. Tomczak, Bydgoszcz.

Lustracja. 1969. Lustracja województw wielkopolskich i kujawskich 1628-1632, cz. II: Województwo sieradzkie, wyd. Z. Guldon, Wrocław-Warszawa-Kraków.

Lustracja. 1996. Lustracja województw wielkopolskich i kujawskich 1659-1665, cz. II: Województwa sieradzkie, tęczyckie, brzesko-kujawskie, inowrocławskie i Ziemia Dobrzyńska, wyd. Z. Górski, J. Pakulski, A. Tomczak, Torun.

Lustracja. 2007. Lustracja województw wielkopolskich i kujawskich 1789, cz. II: Województwo sieradzkie, t. 2: Powiaty piotrkowski, radomszczański, wieluński i ostrzeszowski, wyd. R. Kabaciński, K. Mikulski, J. Pakulski, Torun.

Łaski Jan. 1881. Liber Beneficiorum Archidioecensis Gnesnensis, t. II, wyd. J. Łukowski, Gniezno.

Majewski Marcin Ł. 2017. Węrzy, Szkoci i Ormianie. Studia nad składem etnicznym mieszkańców Piotrkowa przyjętych do prawa miejskiego w okresie staropolskim, Warszawa.

Majewski Marcin Ł. 2019. Piwowarstwo miejskie w Piotrkowie w XVI-XVIII wieku, Warszawa. 
Pacelt Krzysztof. 1989. Stosunki gospodarcze i społeczne w XVI i w pierwszej połowie XVII wieku, [w:] Dzieje Piotrkowa Trybunalskiego, red. B. Baranowski, Łódź, s. 73-83.

Pelc Julian. 1937. Ceny w Gdańsku w XVI i XVII wieku, Lwów.

Pelc Julian. 1935. Ceny w Krakowie w latach 1369-1600, Lwów.

Plisiecki Piotr. 2015. Młyny wodne w województwie lubelskim (do schytku XVI wieku), Lublin.

Rawita-Witanowski Michał. 2017. Monografia Piotrkowa Trybunalskiego, Piotrków Trybunalski.

Rosin Ryszard. 1967. Piotrków Trybunalski w średniowieczu, [w:] 750 lat Piotrkowa Trybunalskiego. Materiały na sesję naukowa, red. R. Rosin, Piotrków Trybunalski, s. 11-42.

Rosin Ryszard. 1989. Dzieje Piotrkowa do przełomu XV i XVI wieku, [w:] Dzieje Piotrkowa Trybunalskiego, red. B. Baranowski, Łódź, s. 11-42.

Rutkowski Henryk. 1967. Piotrków Trybunalski w XVI i pierwszej połowie XVII wieku jako miejsce zjazdów szlacheckich, [w:] 750 lat Piotrkowa Trybunalskiego. Materiały na sesję naukowa, red. R. Rosin, Piotrków Trybunalski, s. 43-74.

Rutkowski Henryk. 1998. Piotrków, [w:] Atlas historyczny Polski. Województwo sieradzkie i województwo tęczyckie w drugiej połowie XVI wieku, cz. II: Komentarz. Indeksy, red. S. Trawkowski, Warszawa, s. 91-97.

Rzepkowski Krzysztof. 2015. Złoty kciuk. Młyn i młynarz w kulturze zachodu, Toruń.

SRP XII. Scriptores Rerum Polonicarum, t. XII, wyd. B. Ulanowski, Kraków 1888.

Szymański Andrzej. 2017. Z dziejów mlynarstwa i piekarnictwa w Pleszewie, Pleszew.

Tomaszewski Edward. 1934. Ceny w Krakowie w latach 1601-1795, Lwów.

Żaba Antonina. 2017. Górnośląskie młyny wodne w relacji z podróży Friedricha Bernharda Wernhera (1690-1776). Cz. 1: Województwo ślaskie, cz. II: Województwo opolskie, [w:] Mtynarstwo tradycyjne - wczoraj, dziś, jutro... Problemy zachowania ginacego dziedzictwa, red. A. Przybyła-Dumin, B. Grabna, P. Roszak-Kwiatek, Chorzów, s. 73-116.

Żerek-Kleszcz Hanka. 1989. Klęski elementarne w dziejach miasta, [w:] Dzieje Piotrkowa Trybunalskiego, red. B. Baranowski, Łódź, s. 159-164.

\section{Milling and baking in Piotrków in the 16th-18th century}

In the early modern period Piotrków was the largest urban centre of the Sieradz voivodship, and counted among the middle-sized towns of the Crown of Poland, having a population of c. 2000 in the second half of the 16th c. Furthermore, it was politically significant as the seat of the general assembly of the Seym of the Crown in the 15th-16th c., and from 1578 the seat of the Crown Tribunal for the province of Greater Poland.

Milling and baking in Piotrków have not been widely researched so far, and they deserve attention as two trades vital for the everyday life of the town's inhabitants. The mill, an establishment where grain and malt were ground, provided the urban community with basic products necessary for making bread and beer.

The article investigates the functioning of mills in Piotrków in the 16th-18th c., and the issue of bread production, on the basis of tax records, guild and Church records, and lease contracts. First, the discussion focuses on the beginnings of local milling, the number, categorization and functioning of mills. Then, matters connected with lease are explored, in particular the conditions of lease contracts, the duties and privileges of millers, the rotation of leaseholders, and the crucial role of women in the running of mills. The second part of the articles is devoted to the baking trade, presenting its beginnings in Piotrków evidenced in written sources, the organization of the trade in the 16th-18th c., the alleged foundation of the bakers' guild in 1630, the figures of several prominent bakers and gingerbread-makers and the prices of bread.

Proofread by Izabela Szymańska 